NBER WORKING PAPER SERIES

\title{
THE RETURNS TO ENTREPRENEURIAL INVESTMENT: A PRIVATE EQUITY PREMIUM PUZZLE?
}

\author{
Tobias J. Moskowitz \\ Annette Vissing-Jørgensen \\ Working Paper 8876 \\ http://www.nber.org/papers/w8876
NATIONAL BUREAU OF ECONOMIC RESEARCH
1050 Massachusetts Avenue
Cambridge, MA 02138
April 2002

We are grateful to several anonymous referees, Rochelle Antoniewicz, Merle Erickson, Eugene Fama, Ken French, Lars Hansen, John Heaton, David Ikenberry, Barry Johnson, Steve Kaplan, Deborah Lucas, Andrew Metrick, Sendhil Mullainathan, Ann Semer, Per Stromberg, and seminar participants at University of Minnesota, the University of Chicago Finance and Macro lunches, and Money and Banking seminar, MIT, UCLA, Arizona State, the New York Federal Reserve, Purdue, Stanford, Berkeley, McGill, University of British Columbia, Ohio State, the NBER Macroeconomic Fluctuations and Corporate Finance meetings, the Berkeley Program in Finance, the Wharton Conference on Household Portfolio Choice, and the WFA meetings for helpful comments and suggestions. Moskowitz thanks the Center for Research in Security Prices and the James S. Kemper Foundation for financial support. Vissing-Jørgensen thanks the NSF for financial support. Special thanks to Jay Ritter for data on initial public offerings and to Taorong Jiang for help with the SDC database. The views expressed herein are those of the authors and not necessarily those of the National Bureau of Economic Research.

(C) 2002 by Tobias J. Moskowitz and Annette Vissing-Jørgensen. All rights reserved. Short sections of text, not to exceed two paragraphs, may be quoted without explicit permission provided that full credit, including (C) notice, is given to the source. 
The Returns to Entrepreneurial Investment: A Private Equity Premium Puzzle?

Tobias J. Moskowitz and Annette Vissing-Jørgensen

NBER Working Paper No. 8876

April 2002

JEL No. G11, G12, M13

\begin{abstract}
We document the return to investing in U.S. nonpublicly traded equity. Entrepreneurial investment is extremely concentrated, yet despite its poor diversification, we find that the returns to private equity are no higher than the returns to public equity. Given the large public equity premium, it is puzzling why households willingly invest substantial amounts in a single privately held firm with a seemingly far worse risk-return tradeoff. We briefly discuss how large nonpecuniary benefits, a preference for skewness, or overestimates of the probability of survival could potentially explain investment in private equity despite these findings.
\end{abstract}

Tobias J. Moskowitz

Graduate School of Business

University of Chicago

1101 E. 58th St.

Chicago, IL 60637

and NBER

tobias.moskowitz@gsb.uchicago.edu
Annette Vissing-Jørgensen

Department of Economics

University of Chicago

1126 E. 59th St.

Chicago, IL 60637

and NBER

vissing@uchicago.edu 
Asset pricing and investment theory rely critically on our understanding of investors' portfolio choices. Yet, entrepreneurial investment, which represents a substantial fraction of many investors' portfolios, is relatively understudied and not particularly well understood. Specifically, little is known about the aggregate return to entrepreneurs' equity investments and the distribution of equity returns across non-publicly traded firms. We analyze investment in and document the return to all non-publicly traded equity in the U.S. The total value of this private equity is similar in magnitude to the public equity market over our sample period. Despite this, the private equity market has received relatively little academic attention. ${ }^{1}$ We provide the first set of estimates of the returns and risks for the entire market of non-public equity.

We find investment in private equity to be extremely concentrated. About 75 percent of all private equity is owned by households for whom it constitutes at least half of their total net worth. Furthermore, households with entrepreneurial equity invest on average more than 70 percent of their private holdings in a single private company in which they have an active management interest. Despite this dramatic lack of diversification, the average annual return to all equity in privately held companies is rather unimpressive. Private equity returns are on average no higher than the market return on all publicly traded equity.

Using data for all private equity from both the Survey of Consumer Finances (SCF) and the Flow of Funds Accounts and the National Income and Product Accounts (FFA/NIPA) over the period 1989 to 1998 as well as proprietor and partnership data from the FFA/NIPA over the longer period 1952 to 1999, we find that the average return to all private equity is similar to that of the public market equity index. This is surprising, since investing in the equity of a single private company is likely to be much riskier than investing in the public equity index. First, survival rates of private firms are only around 34 percent over the first 10 years of the firm's life. Second, even conditional on survival the distribution of equity returns across entrepreneurs is wide. Third, the average entrepreneur holds most of his investment in the same private firm in which he works, making his equity return highly correlated with his human capital return. Fourth, while it is difficult to precisely estimate the overall risk of private equity, our estimates suggest that the index of private equity is likely as volatile as the public equity index and that aggregate private equity returns are highly correlated with the public equity market. Finally, the amount of idiosyncratic

\footnotetext{
${ }^{1}$ While there are some papers which examine venture capital financing of private firms, venture capital accounts for a trivial fraction (less than 1 percent) of the entire private equity market (according to the numbers in George W. Fenn et al. (1995) as well as our numbers for total private equity). In addition, venture capital pertains to a very specific type of investment in private equity that may not provide much insight into the typical entrepreneur's investment decision and returns.
} 
risk of a single private firm implies that the aggregate (index) return is likely an overestimate of the average of the returns to each individual entrepreneur, further strengthening the conclusion that private equity returns are low. Our results are robust to a variety of adjustments for the labor component of entrepreneurial income, retained earnings in the firm, firm births and deaths, initial public offerings and acquisitions, and potential income underreporting due to tax evasion. Overall, the diversified portfolio of public equity seems to offer a far more attractive risk-return tradeoff than that obtained by the typical entrepreneur.

To put our results into perspective, consider what theory suggests the expected private equity return to be. The higher risk from lack of diversification of private equity should lead to a higher private equity premium than that on public equity. How much higher than the average public equity return would we expect the average private equity return to be? John Heaton and Deborah Lucas (2001) model and calibrate the hurdle rate which would make a household indifferent between investing in a portfolio of a single private firm, a public equity index, and T-bills, or a portfolio of just the public equity index and T-bills. For an investor with a relative risk aversion coefficient of 2 (as well as reasonable assumptions about the debt-to-asset ratio of the private firm and the fraction of entrepreneurial wealth invested in private equity), purely idiosyncratic private equity risk generates a hurdle rate of about 10 percent above the public equity return. ${ }^{2}$ Michael J. Brennan and Walter N. Torous (1999) estimate a certainty equivalent wealth loss of investing in a single (public) firm of about 64 percent over a ten year horizon for an investor with a relative risk aversion coefficient of 2. This loss increases to 95 percent for an investor with a relative risk aversion coefficient of 3. Shlomo Benartzi (2000) finds that a return premium of 20 percent is needed for an individual (with relative risk aversion coefficient of 4 ) to invest 45 percent of his portfolio in a single publicly traded stock when the total portfolio is restricted to have 40 percent bonds and 60 percent stock. When allowing the total portfolio to contain 100 percent equity, and reducing risk aversion to 2, the required excess return of the individual stock over the public equity index return declines to 5 percent. Therefore, the premium required to induce investors to hold equity in a single private firm would also have to be large. Moreover, none of these calculations take into account the fact that entrepreneurs' return on human capital is also highly correlated with the firm's equity return. Thus, the additional required expected return to private equity over public equity seems to be at

\footnotetext{
${ }^{2}$ This number is based on the average of line 2 and 3 in Table 4 of Heaton and Lucas (2001). This case corresponds most closely to the ratio of private equity to net worth documented below based on the SCF and the ratio of debt to assets for proprietors and partnerships in the FFA. The authors' calculation assumes a zero correlation between private and public equity (the private investment project in their model has no aggregate risk). A positive correlation would increase the private equity hurdle rate.
} 
least 10 percent per year in order to induce private equity investment. For simplicity, we will cite 10 percent as the required premium for use in some of our "back-of-the-envelope" calculations.

Of course, obtaining a precise measure of the mean return to private equity is extremely difficult. The notoriously difficult exercise of estimating the mean on a highly volatile return series over a relatively short time period is well known. This difficulty is exacerbated when using fairly imprecise data on estimates of private firm values and profits. Nevertheless, the estimated realized returns to private equity are similar to those in the public market, and are highly correlated with public equity returns. Hence, it is quite unlikely that private equity outperformed public equity by 10 percent per year over our sample period (including the longer period from 1952 to 1999). ${ }^{3}$ The implication is that private equity returns appear low given their risk.

In addition to its sheer size, it is interesting to analyze the private equity market to help understand existing asset pricing issues. Consider the "equity premium puzzle" of Lars P. Hansen and Kenneth J. Singleton (1983) and Rajnish Mehra and Edward C. Prescott (1985). Resolutions of the high average return on public equity, which rely on homogeneous agents with very large values of risk aversion (e.g., John Campbell and John Cochrane (1999)), seem at odds with the fact that many households take on much larger risks in the private equity market without, on average, earning a higher return than the public equity return. In other words, unlike the equity premium puzzle documented in public markets, the returns to private equity investment appear far too low given their risk. If households require such a high expected return to take on the risk of publicly traded equity, why are they willing to invest substantial amounts of wealth in a single private company with a much worse risk-return trade-off? Should this be considered a "private equity premium puzzle"? More theoretical and empirical work is needed to determine if this is the case. What we hope to convince the reader is that a complete theory of household portfolio choice should emphasize both public and private equity. For example, John Heaton and Deborah Lucas (2000) argue that the additional risk of private investment and its correlation with public equity market returns may help explain why the (public) equity premium is so high. However, while it is standard in this literature to treat nonfinancial income as exogenous, our findings emphasize

\footnotetext{
${ }^{3}$ For example, suppose private and public equity each have annual returns with (known) standard deviation of 0.17 and a correlation of 0.5 , and that the sample mean return difference is zero. Then, one can reject that the mean return on private equity exceeds the mean return on public equity by more than 4.1 percent per year at the 5 percent significance level with 47 annual observations. With zero correlation between private and public equity, one can reject that the difference exceeds 5.8 percent at the 5 percent level. This does not account for measurement error in our private equity returns or uncertainty about the variance or covariance. Nonetheless, it suggests there is hope to establish, in a statistical sense, that the mean private and public equity returns are closer than predicted by existing theory.
} 
that a complete understanding of investor portfolio choice requires private equity holdings to be endogenized.

An alternative interpretation of our results is that they raise the question "why do people become entrepreneurs?" This decision is based on both the equity return as well as the return on human capital. Since our equity return estimates account for the labor component of entrepreneurial activity, finding a low equity return makes the decision to become an entrepreneur somewhat puzzling. ${ }^{4}$ In the final part of the paper, we briefly discuss possible theories for what motivates entrepreneurs to enter into entrepreneurship and hold such undiversified portfolios of private equity, despite the unattractive risk-return trade-off. We consider five possible explanations for entrepreneurial investment: high entrepreneur risk tolerance, large additional pecuniary benefits, large nonpecuniary benefits, a preference for skewness, and overoptimism and misperceived risk.

The most related work to our paper is Barton H. Hamilton (2000), who documents that individuals in the 1984 Survey of Income Program Participation (SIPP) choose self-employment despite facing a median (but not mean) stream of future earnings significantly less than that available as a paid employee. In addition, the cross-sectional standard deviation of self-employed earnings is substantially larger than that of wages from paid employment. Hamilton (2000) interprets these results as evidence that large nonpecuniary benefits to self-employment exist. Our data allow for a more comprehensive treatment of the equity return component of the entrepreneur's payoff over a longer time period, including adjustments for firm entry and exit. ${ }^{5}$

The rest of the paper is organized as follows. Section I briefly describes the data used in this study, highlighting the combination of data sources used to analyze the diversification of and returns to private equity. Section II documents the poor diversification of entrepreneurial/private equity investment and compares it to ownership of publicly traded stock in firms for which a household member works. Section III conducts a detailed analysis of the returns to private equity, highlighting a series of issues in calculating these returns and Section IV examines the risks of private equity investment. Based on this risk-return tradeoff, the observed concentration of wealth in private

\footnotetext{
${ }^{4}$ Even if the conditional return distribution for some entrepreneurs is attractive given their information, this would only mean that the conditional distribution of returns for other entrepreneurial activities would be even less attractive. Hence, the unattractiveness of the unconditional private equity return distribution indicates that the motivation for at least some group of entrepreneurs is puzzling.

${ }^{5}$ Hamilton (2000) employs various income measures to capture both the labor component of earnings and the private equity return. His results on the mean payoff are sensitive to the measure used, while the median payoff is substantially below the outside option irrespective of the income measure used. Given the limited amount of equity information in his sample (only one year of equity return data for a fraction of the sample), he focuses on the median entrepreneur rather than the mean.
} 
firms appears puzzling. Section V considers various explanations for why investors may become entrepreneurs and willingly hold so much undiversified private equity. Finally, Section VI concludes with a discussion of the results.

\section{Data Sources}

In order to analyze private equity holdings and returns, we use data from several sources.

\section{A. The Survey of Consumer Finances}

The first is the 1989, 1992, 1995, and 1998 Survey of Consumer Finances (SCF). These surveys are nationally representative samples of about 4,000 households per survey year. Weights are provided to allow aggregation to U.S. totals. A high wealth sample is included, which improves the accuracy of estimates of aggregate wealth and its components. The respondents provide information on individual household portfolio composition, including investment in both private and publicly traded firms. Furthermore, characteristics of the household are provided on employment status, hours worked per week, demographics and educational attainment, as well as on the attributes of private firms in which the household has ownership. Weighting households using the SCF weights, about 11 percent of respondents report to have some ownership in a nonpublicly traded firm (28 percent when not weighting).

Table 1 reports summary statistics on the private equity investments in the SCF. Panel A documents the percent of total private equity in various lines of business. The set of private equity investments span a variety of industries. Our computation of the returns to private equity encompasses all of these entrepreneurial activities. However, note that the data is not dominated by any particular industry. A significant fraction of entrepreneurs are in manufacturing (21.4 percent) and service industries (30 percent) as well as retail (21.8 percent). Likewise, activities that may be more consistent with consumption or hobbies rather than investment (e.g., restaurants, bars, weekend ranches, etc.) represent a small fraction of our data.

Panel B reports the distribution of entrepreneurs across various household and firm characteristics using data for the firm in which the household has its largest actively managed equity share. Most of the entrepreneurs are male. 40.3 percent have a college degree. The average age of our entrepreneurs is 46.5 , with 90 percent of the sample below 65 years of age. Thus, the majority of private equity investors with active management interests in our sample are below retirement age and therefore are not individuals looking for a "hobby" in retirement. Finally, there is a wide 
range of firm sizes in the sample (measured by equity, sales, profits, and number of employees) with significant right skewness.

\section{B. Flow of Funds and National Income and Product Accounts}

As an additional supplement to our private equity data, we also employ equity data from the Federal Reserve Board's Flow of Funds Accounts (FFA) and income data from the National Income and Product Accounts (NIPA) over the 1952 to 1999 time period. This data source provides aggregate statistics on the value and income of corporate and non-corporate firms on an annual basis. We employ this data to generate a longer time-series of private equity returns.

\section{Other Data Sources}

We also supplement our return calculations with adjustments for IPOs (provided by Jay Ritter), merger and acquisition activity in private and public markets (from the Securities Data Corporation (SDC)), as well as public stock return information from the Center for Research in Security Prices (CRSP) and accounting information on public firms from Compustat. Data from the 1993 National Survey of Small Business Finances (NSSBF) are also used to supplement our calculations. ${ }^{6}$

\section{Entrepreneurial Equity Concentration}

We start by comparing the level of diversification of private equity investors to that of public equity investors, focusing on ownership in publicly traded corporations for which a household member is or has been employed as the most severe candidate for poor diversification. We find that private equity investors are dramatically less diversified than public equity investors.

\section{A. Ownership in Privately Held Firms}

Using data from the SCF, Panel A of Table 2 documents the poor diversification of household portfolios in private equity. The value of private equity for a given household is the self-reported value of the household's share of net equity in the business if it were sold today. (Possible reporting bias issues are addressed later in the paper.) We account for entrepreneurial leverage in the firm by adding loans from the household to the business and subtracting loans from the business to the household. We exclude the value of personal assets used as collateral for business loans. This is

\footnotetext{
${ }^{6}$ The 1993 NSSBF is a firm-based survey of small businesses sponsored by the Federal Reserve Board to provide detailed information on a representative sample of private, nonfinancial, nonfarm businesses with less than 500 employees. The sample represents the population of about 5 million small businesses in the U.S. in operation as of December, 1992. The sample covers 4,637 small companies.
} 
done to be conservative, but does not materially affect the results. Summary statistics are reported for each survey year $(1989,1992,1995$, and 1998) as well as the average across years. All figures are calculated using SCF weights, and are thus representative of the population of U.S. households. We average dollar values across the five SCF imputations.

The first three rows of Panel A report the percent of total private equity owned by households with various degrees of net worth devoted to private equity. A little more than 75 percent of all private equity was held by households who had 50 percent or more of their net worth devoted to private equity. A more direct measure of the poor diversification caused by investment in private equity is captured by the next two rows of Panel A. The rows report the average percent of net worth invested in private equity across all households with some private equity holdings and positive net worth. The average household in this group invests 41 percent of its wealth (45 percent when weighting by net worth) in private equity, consistent with the findings of William M. Gentry and R. Glenn Hubbard (2000). This figure does not account for human wealth and the fraction of this derived from labor income in the firm. Moreover, this investment is typically devoted to a single private firm in which the household has an active management interest. The next two rows of Panel A report the mean percent of private equity held in the firm representing the household's largest actively managed equity position. The average household who owns private equity has 82 percent (73 percent when weighted by amount of private equity invested) of its private equity investment in such a firm. Moreover, more than 86 percent of total private equity is held by investors with an active management role in the company in each year of the SCF. Overall, these results indicate that not only is private equity investment substantial relative to net worth, it is also poorly diversified and concentrated in the hands of managers.

\section{B. Own Company Stock Ownership in Publicly Traded Firms}

For comparison to the concentration of wealth in private equity, we document the prevalence of holdings in public firms in which a household member is or has been employed.

Panel B of Table 2 reports that for households with own company stock holdings, these constitute the majority of the households' direct equity investment, averaging 73.8 percent (50.2 percent when weighted by amount of directly held public equity). As a fraction of all public equity held, both directly and indirectly through mutual funds, IRAs, pension plans, and annuities and trusts, own company stock accounts for about 52.4 percent (34.1 percent when weighted by amount of total public equity invested) of a household's total public equity holdings. Relative to net worth, 
however, investment in own company stock for public firms is far less important. As a fraction of household net worth, investment in own company stock is only 10 percent, compared to 45 percent for private firms. Furthermore, households with over 25 percent or more of their equity holdings in own company stock own only about 12 percent of total equity investment in public firms. Households with at least 50 percent and 75 percent of their equity holdings in own company stock comprise only 8 and 4 percent, respectively, of total public equity investment. Hence, owners of own company stock in public companies are not as poorly diversified as owners of private equity and own only a small fraction of public equity. ${ }^{7}$ It should be noted that households may hold undiversified portfolios of public equity without owning any own company stock. However, Annette Vissing-Jørgensen (1999) shows that 91.3 percent of public equity held in the 1995 SCF is owned by households with at least 5 directly held stocks or half or more of their equity holdings in indirect form (e.g., mutual funds, retirement plans, etc.). This underscores the importance of analyzing and understanding investment in private equity.

\section{The Returns to Private Equity Investment}

Due to the lack of a comprehensive panel data set on entrepreneur investments, we examine the returns to an index of all private equity by aggregating all the private firm values and profits to U.S. totals. Only by aggregation can we account for firm entry and exit over time and assign the proper returns. In the next section we argue that the private "index" return is likely to be an upward biased estimate of the average individual firm return (when focusing on geometric buy and hold returns).

\section{A. The Size of the Private Equity Market}

We begin by first comparing the size of the private and public equity markets. We employ two data sources for our estimates of the size and returns of this market. The first is the 1989, 1992, 1995, and $1998 \mathrm{SCF}$ and the second is the FFA from 1952 to $1999 .{ }^{8}$ Panel A of Table 3 reports the

\footnotetext{
${ }^{7}$ The numbers in Table 2 do not include own company stock held indirectly through pension plans or employee stock ownership plans (ESOPs). However, the Department of Labor estimates (based on Form 5500 filed with the Internal Revenue Service) that of the total $\$ 1,024$ billion in assets of defined contribution plans with 100 or more participants in 1995, $\$ 165$ billion was invested in employer stock. ESOPs with 100 or more participants account for another $\$ 100$ billion of investments in employer equity. Based on the $1995 \mathrm{SCF}$, the total dollar amount of directly held own company stock is $\$ 272$ billion, about the same as holdings through pension plans and ESOPs combined. The total amount of direct and indirect holdings of publicly traded stock by households in the 1995 SCF is $\$ 3,439$ billion, implying $\frac{165+100+272}{3439}=15.6$ percent of total public equity is owned by employees. This is still considerably less concentrated than private equity.

${ }^{8}$ For a comparison of the SCF and FFA equity numbers, as well as the numbers for many other asset categories, see Rochelle L. Antoniewicz (2000).
} 
size of the private equity market estimated from the SCF using the household weights provided. Total market value of private equity held in billions of dollars are reported for two types of firms: proprietorships and partnerships, and S and other corporations (with unknown firm types included in the latter category). In computing the total amount of private equity investment (and their returns) we again deduct collateral posted by the entrepreneur for loans to the firm. This is done to be conservative so that private equity values will not be inflated by the inclusion of personal assets posted as collateral.

As Table 3 shows, the market value of private equity has risen steadily from 1989 to 1998, in large part due to an increase in $\mathrm{S}$ and other corporations. The total dollar amount of private equity is substantial, ranging from $\$ 3.7$ trillion in 1989 to $\$ 5.7$ trillion in 1998 . The SCF estimate of the total holdings of public equity by households has similarly risen sharply over the decade covered by the four surveys (from $\$ 1.6$ trillion to $\$ 7.3$ trillion). ${ }^{9}$ The growth in public equity value has outpaced that of private equity. The private market was 2.3 times larger than the public market in 1989, but was only 79 percent as large as the public market by the end of 1998. This suggests that the returns to public equity were larger than those of private equity over this time period. Also reported is the average price-to-earnings ratio $(\mathrm{P} / \mathrm{E})$ and price-to-dividends ratio (where dividends are profits minus retained earnings minus a labor adjustment described below), which average 5.1 and 11.6 over the sample period, respectively in the private market. These are significantly smaller than those in the public market.

We also estimate the size of the private equity market from data obtained from the FFA. For comparison to the SCF estimates, we show the FFA data for 1989, 1992, 1995, and 1998. FFA noncorporate equity is defined as tangible and financial assets minus liabilities. Tangible assets consist of real estate (at estimated market value) plus equipment, software, and inventories (at replacement cost). As described in Antoniewicz (2000), the FFA noncorporate equity includes the market value of 1-4 family rental properties. To obtain a number more comparable to the SCF, we subtract from the FFA number an estimate (based on aggregate data from the Bureau of Economic Analysis) of the market value of such properties.

The resulting estimates of (noncorporate) proprietorship and partnership equity are similar to those from the SCF in Panel A. The FFA numbers for equity in corporations are more problematic.

\footnotetext{
${ }^{9}$ These numbers include estimates of households' ownership of public equity through mutual funds, defined contribution retirement plans, and trusts. Since part of public equity is owned by defined benefit retirement plans, including state and local government retirement plans, or by non-profit organizations, insurance companies, and foreigners, the SCF public equity totals will be lower than the CRSP total market value for public equity.
} 
First, equity in S and C corporations refer to both equity in publicly traded corporations and equity in privately held firms. The FFA estimates the value of closely held (nonpublic) corporations from estate tax returns, but do not publish separate series for publicly traded corporate equity and nonpublic corporate equity. The specifics of the approach are proprietary and they would not release their series. To obtain an estimate of nonpublic corporate equity, we considered subtracting from the FFA number the estimate of the market value of public equity from CRSP, which is reported at the bottom of Table 3 in Panel C. However, this produces an extremely volatile S and C private equity series since it is the residual, which thus also captures any definitional differences between the FFA and CRSP. As an alternative measure (that is still independent of the SCF equity totals), we adopt a method used by the IRS for estimates of wealth that is also based on estate tax returns, see Barry W. Johnson (2000). This method is useful since the vast majority (over 90 percent) of equity in private corporations is owned by the population represented on estate tax returns (i.e., those with assets over $\$ 600,000)$. The estimation relies on an estate multiplier which reflects the probability that a given dollar of wealth shows up on estate tax returns for a given year. The multiplier used by the IRS is around 100 from 1989 to 1995 . We report numbers for multipliers of 200 and 300, which we argue is a better multiplier for private equity holders, who are unlikely to have the same mortality rates as the general population in the same age and wealth cohort. While obtaining precise multipliers is difficult, Appendix A provides some support for our multipliers based on health and expected life span questions from the SCF. This method can only be applied to the FFA figures from 1989 to 1999, but not for the longer period 1952 to 1999 due to data limitations. Consequently, we will focus on proprietorships and partnerships from the FFA when examining the longer time period. The FFA estimates of corporate private equity obtained by this method are slightly smaller than the estimates based on the SCF when using a multiplier of 200 and slightly larger using a multiplier of 300 .

Using these numbers, the total size of the private equity market based on the FFA/estate tax return data is substantial, and is larger than the public equity market in the 1989 data. Accounting for the fact that individuals own about 70 percent of public equity (direct and indirect holdings), the ratio of private-to-public equity held by households is again large. Using these private equity values as well as estimates of firm profits (discussed below), we document the returns to private equity investment. 


\section{B. Returns to an Index of All Private Equity}

We begin by calculating the returns to a value-weighted index of all private equity based on the 1989 to 1998 SCF data. In order to estimate the returns to private equity holdings, we use the household estimates of the market value and profits of the private firms being held as reported in Table 3. The profits reported by households are pre-tax earnings for the year prior to the survey. Although these numbers are self-reported by households, they are anonymous and not subject to tax scrutiny. However, we will address later whether reporting biases are likely to have influenced our return calculations and how we can account for these possible distortions.

We first convert pre-tax earnings of $\mathrm{C}$ corporations into after tax profits by subtracting an estimate of the taxes due assuming a 30 percent corporate tax rate. Table 3 reports both the pre-tax profits of proprietorships and partnerships and after tax profits of corporations (with no adjustment for $\mathrm{S}$ corporations who are exempt from corporate taxation). Since earnings are reported for the year prior to each survey (and surveys occur only every three years), we report the average of the returns obtained using the current and the previous survey's earnings estimates. Thus, the returns over the first survey period 1990 to 1992 are the average of the geometric annualized returns using 1988 and 1991 earnings, respectively.

To avoid double counting earnings as both a potential dividend to investors as well as a capital gain, we make an assumption about the fraction of (after-tax) earnings that are retained in the firm. Since the SCF does not record how much of earnings are paid out to shareholders, we assume that 40 percent are retained in $\mathrm{C}$ corporations. This corresponds roughly to the ratio of retained earnings to after tax profits for public C corporations in the NIPA data over the period 1989 to 1998. External financing is likely to be more costly for private firms than for larger public firms. Therefore, it is likely that private $\mathrm{C}$ corporations retain more in the firm than larger public firms. Increasing the retention rate would lower our subsequent return estimates, hence the 40 percent retention assumption will, if anything, bias our returns upward. Since S corporations, proprietorships, and partnerships are often smaller than $\mathrm{C}$ corporations, one may expect them to face even higher costs of external financing and thus have higher retained earnings. On the other hand, they may have fewer growth opportunities, so we conservatively assume their retention is half that of $\mathrm{C}$ corporations (i.e., 20 percent). Profits after retained earnings are reported in Table 3.

Using the market value of private equity at the beginning and end of each survey period, plus 
the after-tax profits of the firm, adjusted for retained earnings, we compute the return on private equity over the years between each survey. Table 4, Panel A reports the geometric average annual return from investing in private equity over the three survey periods. From 1990 to 1992, the average return is 12.3 percent per year, from 1993 to 1995, the average return is 17.0 percent, while it is 22.2 percent from 1996 to 1998.

Panel B of Table 4 reports the returns to the CRSP value-weighted index of NYSE, AMEX, and NASDAQ public equity over the same time period for comparison. The geometric average annual return to public equity is $11.0,14.6$, and 24.7 percent for the 1990 to 1992,1993 to 1995 , and 1996 to 1998 periods, respectively. These returns are similar to those from private equity in the SCF (a bit lower from 1993 to 1995). Since private firms are much smaller and riskier than large public companies, represented by the CRSP value-weighted index, perhaps a better comparison is to the returns on the smallest decile of publicly traded firms. Over the three survey periods, the geometric average annual returns on the smallest decile of CRSP firms is 30.47, 20.27, and 22.00, respectively. These are considerably higher than the private equity returns for the 1990 to 1992 period and quite similar for the other two periods. Other small firm indices performed worse than the CRSP index in the 1990's, however. Given the disparity in performance across various small firm indices in the 1990's, we compare the private equity returns for this period to the returns on the entire public index.

These are our basic private equity return estimates, which are likely to be biased in several ways. In the rest of this section, we quantify these biases as best we can. Correcting for some of the biases leads to higher private equity returns while correcting for others leads to lower private equity returns. We will argue, however, that our most accurate private equity returns are lower than those reported above.

\section{B.1 Accounting for Labor Income}

The most important effect not accounted for above is that the private equity returns contain the part of profits that reflects the labor input of the entrepreneur. This component is not return to equity, but rather captures the fact that many entrepreneurs do not pay themselves a salary. For these entrepreneurs, part of their companies' profits should be viewed as payment for hours worked, rather than return on equity.

Specifically, our baseline return estimates account for salaries withdrawn from the private firms by self-employed managers, since they are already subtracted from the earnings numbers reported 
(for reference, the amount of such salaries are reported in Table 3). However, the SCF private equity holders include many respondents with actively managed equity positions who do not report a salary to themselves. Therefore, we make an adjustment to earnings for this labor component for individuals (head and/or spouse) who report being self-employed, have ownership in a private company in which they have an active management interest, but fail to report a salary taken. To do so, we use the reported weeks worked per year and hours worked per week. We multiply the annual hours worked by an estimated wage rate for similar individuals in the survey who worked in paid employment. Specifically, for respondents who reported to work in paid employment (i.e., not self-employed), we regress their hourly wage rate on a constant, their age, age squared, a dummy variable for having a high school diploma but not a college degree, a dummy for graduating college, and a dummy for their gender. We run one regression for heads of households (defined as the male in couples) and one regression for spouses. Using the regression coefficients, we then estimate the wage rate for self-employed individuals who do not report a salary by multiplying their demographic and education characteristics by the estimated coefficients and using the predicted value as their hourly wage rate. This procedure does not account for any unobserved differences between self-employed and other individuals. In fact, the results of Hamilton (2000) suggest that this should lead to a labor adjustment that is too small, thus biasing our private equity return estimates upward. He shows, using a sample selection model, that the mean wages of employees are less than the expected wages of entrepreneurs had they been paid employees. Furthermore, entrepreneurs returning to paid employment are found to earn a higher wage than other employees with the same observable characteristics. These findings suggest that more talented individuals self-select into entrepreneurship. ${ }^{10}$

We then subtract the estimated annual wage for those not reporting a salary from earnings and recompute returns. The fourth row of Table 4 Panel A shows that the labor adjustment reduces the estimated returns by about 4 percent per year (6.5 percent for proprietors and partnerships and 1.2 percent for $\mathrm{S}$ and $\mathrm{C}$ corporations), indicating its importance in these calculations. With this adjustment, returns to private equity are considerably smaller than those for public equity.

\footnotetext{
${ }^{10}$ As a check on our procedure, we also compare the salaries taken by self-employed households who do report a salary to what our regression approach would have predicted their salary to be. The average reported salary across all entrepreneurs, who report a salary, is 1.16 times the salary our regression approach suggests. (For proprietorships, partnerships, and $\mathrm{S}$ corporations this ratio is 1.10 , for $\mathrm{C}$ corporations it is 1.33 ). This likely confirms the selection issues emphasized by Hamilton (2000). For C corporations it may alternatively reflect excessive salaries reported by some entrepreneurs for tax reasons. Using estimated, rather than actual reported salaries, for C corporations only has a small effect on returns.
} 


\section{B.2 Accounting for Firm Entry: Births and New Equity}

The previous computations assume that the composition of firms in the SCF is the same at the beginning of each three year survey period as it is at the end. While the SCF employs the same sampling procedure and questions for each of the surveys, there will be sample composition differences between survey years that may distort the return estimates.

First, a possible distortion of the composition of firms that comprise the beginning and end of period private equity values occurs when new private firms are "born" between the two survey years. Since end of period figures contain firms created after the previous survey, the values should not be attributed to initial equity holders from the previous survey year. To take this into account, we recompute returns by dropping firms at the end of the period that were founded (but not those that were bought or inherited) less than three years ago. This is done for the earnings estimates and labor component computations as well. The returns drop by 0.7 to 2 percent per year.

Similarly, new equity invested in existing firms should not be attributed as a capital gain to original private equity holders. To estimate the average value of new equity injected into private firms each year, we employ data from the 1993 NSSBF. In this survey, respondents are asked "During the last three years, has the firm obtained additional equity capital from existing owners, their relatives, or from new or existing partners?" And if yes, how much? Using the NSSBF weights, one can aggregate the responses to U.S. totals and divide by 3 to get annual numbers. The aggregated annual total for 1993 was 28 billion dollars, when excluding funds raised for "business expansion, acquisition" and excluding the few public firms in the NSSBF. Since the population of firms covered by the NSSBF have fewer than 500 employees, equity raised by the biggest private firms will not be covered. Thus, our returns may be overstated. As we do not have annual data for this adjustment, it is not included in Table 3. However, this effect likely cancels with an omitted effect from firm exit, which we describe below.

\section{B.3 Accounting for Firm Exit: IPOs, Mergers and Acquisitions, Deaths and Liqui- dations}

As will be documented in the next section, exit rates for private firms are large, and include sale to new owners (including acquisitions and IPOs) as well as liquidations and failures. If a firm goes public between two surveys, then it will no longer be contained in the end of period figures for private equity. Since IPOs are generally the most successful private companies, ignoring these would understate the returns to private equity. To take this into account, we add the total market 
value of all initial public offerings over the three years between surveys to the end of period value of private equity. The effect of IPOs is rather small, increasing average returns by only about 50 basis points per year.

Another possible distortion concerns merger and acquisition activity between the survey years. Specifically, when a private firm is bought out by a public company between surveys, the value of that private firm will no longer be contained in the end of period private equity value. Ignoring this will understate returns. As for sale to new private owners, no adjustment to private equity returns is needed if the new owners hold as much equity in the firm as did the previous owners. If the previous owners get more equity out than the new owners put in (i.e., due to increased financing with debt or internal funds, or from foreign equity investors) then our private equity returns should be increased by the amount of the difference. That is, we need to account for any "new equity" raised at the time of the transaction. Therefore, we need to determine the extent to which private firms are acquired by public companies (whether foreign or domestic), by foreign private companies (irrespective of how funded), and by private companies (foreign and domestic) funded by debt or internal funds, and add back these components to private equity values.

On the other hand, if domestic private firms raise new equity to acquire foreign targets, this should be subtracted from our private equity totals, since the gains from such acquisitions will accrue to foreign entrepreneurs. Likewise, public firms acquired by private firms funded with newly raised equity will also overstate our returns. Hence, we need to subtract these from private equity totals.

To account for these effects, we examine the total dollar amount and number of transactions of merger and acquisition activity in private and public firms using data from Securities Data Corporation (SDC) over the period 1989 to 1998. We focus only on completed transactions and whether the acquirer and target is a private or public firm, whether foreign or domestic, and whether the acquisition was funded with equity or with debt or internal funds. ${ }^{11}$

Table 6 reports the total dollar amount in millions and total number of transactions involving public firm acquisitions of private firms, private firm acquisitions of other private firms, and private acquisitions of public firms over each of the three subperiods from 1990 to 1998. Each of these

\footnotetext{
${ }^{11} \mathrm{SDC}$ records a host of information about global merger and acquisition activity from 1983 to 2001, including public status of the target and acquirer, where it is located, and the source of funds employed in the deal. The sources of funds include borrowing from outside lenders, bridge loans, debt issues, foreign lenders, junk bonds, credit lines, and mezzanine financing, which we code as "debt" sources, as well as funding from internal sources. We aggregate all deals with debt or internal funds sources into one category. The rest are deals funded by common and preferred equity.
} 
categories is further broken down into domestic targets and acquirers, foreign targets and acquirers, and deals funded by debt or internal cash. One problem with the SDC data is that a significant number of deals have missing values. Consequently, the total value reported only pertains to those deals with available price information, which are typically the largest transactions. Rather than employing the average value for the missing observations, which would overstate our private equity numbers, we estimate the value of missing deals using a predictive regression approach similar to that employed for entrepreneurs with missing salary. The details are provided in Appendix B. These estimated values are added to the value of deals with price information to produce a total or "scaled" value for each subcategory. Table 6 reports the sum of these values over the three subperiods. The sum of all changes are added to the end of period total value for private equity in Table 3.

As indicated in the ninth row of Panel A of Table 4, accounting for mergers and acquisitions adds an additional 0.4 percent per year to private equity returns over the 1990 to 1992 period, about 1 percent per year from 1993 to 1995, and 2.3 percent per year from 1996 to 1998 . However, the modified returns remain substantially below the returns to public equity.

The SDC database covers the largest mergers and acquisitions. Data on sales of small businesses to new owners as well as equity recovered in liquidations is not available annually. To evaluate the impact of such transactions, we use the 1993 NSSBF. A conservative estimate of these possible effects can be calculated as follows. According to the U.S. Small Business Administration (2000) about 500,000 employer firms discontinued each year during the 1989 to 1998 period. The upper bound on the decrease in firm equity at sale or liquidation is the amount of assets held by such firms. In the $1993 \mathrm{NSSBF}$ the median asset holdings for all firms with less than 500 employees (using NSSBF weights) is about $\$ 70,000$. Thus, if the typical discontinued firm was of median size, the upper bound on the total adjustment necessary is 35 billion dollars per year. In reality, most of the discontinued firms are liquidations or failures rather than sales to new owners (see Section IV). Thus, the relevant adjustment is much smaller than 35 billion dollars and therefore likely cancels with the 28 billion of newly raised equity by existing firms discussed in the previous subsection.

We believe the returns in line 9 of Table 4 are the most accurate returns to private equity. The following summarizes our computations and various adjustments to earnings and private equity values in Table 4 ,

$$
R_{t: t+3}=\frac{A M V_{t+3}+A E_{t: t+3}}{A M V_{t}}
$$




$$
\begin{aligned}
A M V_{t+3} & =M V_{t+3}+I P O_{t: t+3}+M \& A_{t: t+3}-M V_{t+3}^{a g e<3} \\
A E_{t: t+3} & =\left(E_{t: t+3}-E_{t: t+3}^{a g e<3}\right)\left(1-\tau_{c}\right)\left(1-r_{R E}\right)-L C_{t: t+3} \\
\tau_{c} & =\text { tax rate; } 0.30 \text { for C Corps., } 0 \text { for } \mathrm{S} \text { Corps. and } \mathrm{P} \& \mathrm{Ps} . \\
r_{R E} & =\text { earnings retention rate; } 0.40 \text { for C Corps., } 0.20 \text { for S Corps. and } \mathrm{P} \& \mathrm{Ps} .
\end{aligned}
$$

where $R_{t: t+3}$ is the return over the three year period between surveys (which is reported as a geometric average annual return). $A M V_{t+3}$ is the aggregate market value of all private firms three years or older at time $t+3$, plus the value of private firms in existence at date $t$ who went public or were acquired by a public firm between dates $t$ and $t+3$. $A E_{t: t+3}$ is the aggregate earnings of all private firms from date $t$ to $t+3$. IPO $O_{t: t+3}, M \& A_{t: t+3}$, and $L C_{t: t+3}$ are the total value of IPOs, public acquisitions of private firms, and the labor component of profits, respectively, over the period $t$ to $t+3$. Different return estimates in Table 4 add or delete these various adjustments.

\section{Returns Across Firm Type}

The returns to private equity we have documented pertain to all firms not held publicly. While we would like to compute private equity returns across industries, this cannot reliably be done using the SCF data given the fairly small number of observations in each of the industry categories. As noted in Table 1, our sample of entrepreneurs are not dominated by any particular industry.

We can, however, compute returns separately for proprietors and partnerships and S and C corporations using the $1993 \mathrm{NSSBF}$ to estimate the percent of proprietor and partnership equity which "migrates" to S and C corporation equity each year. The NSSBF provides both current and 1992 fiscal year corporate status, from which we can quantify the migration of firms from $\mathrm{P} \& \mathrm{P}$ to S\&C. This is important since many of the most successful P\&P firms become $\mathrm{S} \& \mathrm{C}$ corporations as they expand. We estimate the migration rate from $\mathrm{P} \& \mathrm{P}$ to $\mathrm{S} \& \mathrm{C}$ to be 2.1 percent of proprietor and partnership equity per year. ${ }^{12}$ Using this rate, as well as attributing all IPO and merger activity to $\mathrm{S} \& \mathrm{C}$ corporations, and employing a labor adjustment of 6.5 percent for $\mathrm{P} \& \mathrm{P}$ and 1.2 percent for $\mathrm{S} \& \mathrm{C}$, lines 10 and 11 of Table 4 report returns across the two firm types. With all of the return adjustments, returns to equity in $\mathrm{S} \& \mathrm{C}$ corporations are 2.3 percent per year higher from 1990 to 1992, 8.7 percent higher from 1993 to 1995, and 7.4 percent higher from 1996 to 1998 than returns to equity in $\mathrm{P} \& \mathrm{P}$ firms. However, even the higher $\mathrm{S} \& \mathrm{C}$ returns are lower than those of the public market in two of the three subperiods. Public equity outperformed P\&P private equity in all three

\footnotetext{
${ }^{12}$ This may even be overstated since the survey was fielded between March, 1994 and January, 1995. Thus, the two firm type observations are more than one year apart.
} 
subperiods by between 4 and 9 percent per year. We now consider further robustness checks on the SCF private equity returns.

\section{Robustness of the Return Estimates}

We consider robustness issues and possible reporting biases in the SCF to gauge whether these could distort our return estimates.

\section{D.1 Retained Earnings Sensitivity}

For robustness, and as an overestimate of the returns to private equity, the twelfth row of Panel A assumes that proprietors, partnerships, and $\mathrm{S}$ corporations do not retain any earnings. This is an extreme assumption since it implies that actual retained earnings for these firms will be double counted as both a dividend and capital gain. However, the private equity returns are still below those of the public market in 2 of the 3 time periods.

\section{D.2 Understated Profits Due to Tax Evasion?}

Since the SCF is based on interviews and not tax returns, it is not clear whether respondents report their true profits or the profits as stated on their tax forms. However, as long as respondents trust that the SCF will not release information to other government agencies (which the SCF goes to great lengths ensuring), households have no incentive to hide their true profits. This is supported by the fact that the SCF profits for P\&Ps are quite close to the corresponding NIPA profits (proprietor's income). The latter are based on profits as reported to the IRS with a 75 percent adjustment for income underreporting on tax returns (more detail below). The SCF profits are almost identical to the adjusted NIPA profits in 1992 and within 15 percent of the NIPA profits in the other three years. Furthermore, evidence from evaluation studies of the 1977 economic censuses also suggests that households do in fact report their true income to surveys (but not to tax authorities). For these censuses, the Census Bureau conducted additional special surveys of small firms for which tax return information had been used in the original economic censuses. The income reported in the special surveys consistently exceeded the information based on tax returns. In fact, the underreporting in the original censuses based on tax returns was found to be about the same as the amount of tax return underreporting estimated (independently) by the IRS. In other words, respondents to the special census surveys did seem to report their true income. ${ }^{13}$ Thus, if

\footnotetext{
${ }^{13}$ See Robert P. Parker (1984) and Carol S. King and E. K. Ricketts (1980) for information on these issues.
} 
households report as truthfully to the SCF as they did to special census surveys, we should not need to make any adjustments for income underreporting due to tax evasion.

\section{D.3 Reporting Biases?}

The imputations and weights in the SCF are designed to allow aggregation of the survey figures to represent the aggregate wealth of households in the U.S. population. Since our return estimates are derived from market value and earnings figures provided by the households themselves, one wonders whether reporting biases are affecting our results. Moreover, one wonders what a household's incentive to respond to the survey is, and whether this results in reporting biases. While it is difficult to assess respondent incentives, the SCF is considered quite accurate and relatively free of biases. ${ }^{14}$ Nevertheless, to address possible reporting biases and potential issues involving survey weights and imputations, we calculate returns based on data from the FFA/NIPA in the next subsection and find returns similar to those of the SCF.

To determine whether there is any general reporting bias in the SCF equity numbers, or problems with using survey weights or imputations, we use the SCF to construct public equity returns, and then compare them to those from CRSP. As Panel B of Table 4 reports, the public equity return numbers from the SCF are 2 to 6 percent higher than the CRSP returns. Since the CRSP data implicitly takes into account IPOs and merger activity, but the SCF data may not, we make an adjustment for this (subtracting the value of IPOs but adding the value of public firms taken over by private firms). This has a small effect but increases the return estimates further. Thus, if there is a reporting or weighting bias, it seems to run in the wrong direction to reconcile our low private equity return numbers. ${ }^{15}$

Since price information is more readily available in public markets, it is possible that reporting distortions may be more prevalent in the private equity figures. Respondents may report stale values of private equity that may lag the public market. Since public equity performed remarkably well from 1989 to 1998, this may explain the low SCF private equity returns. Like private equity, owner-occupied homes are illiquid assets that are likely to suffer from similar reporting biases. To defend the survey numbers themselves, we therefore examine housing returns by calculating the

\footnotetext{
${ }^{14}$ See Robert B. Avery et al. (1988), Arthur B. Kennickel and Martha Starr-McCluer (1994), Arthur B. Kennickel et al. (1997), and Arthur B. Kennickel et al. (2000) for a discussion of the survey and weighting schemes, as well as the SCF codebook.

${ }^{15}$ It should be noted that for some account types in which public equity is held, the SCF only provides categorical information about holdings, e.g. 'mostly stocks', 'mostly bonds' or 'a combination of stocks and bonds'. This by itself could lead the public equity returns calculated using the SCF to differ a bit from the CRSP returns, but should not cause a systematic bias.
} 
capital gain on detached single family homes using the SCF data and comparing it to the capital gain on such properties based on data from the Office of Federal Housing Enterprise Oversight (OFHEO). The two sets of numbers differ in that the SCF numbers are based on households' selfreported estimates of what they think they could sell their house for, whereas the OFHEO numbers are based on actual repeat sales housing transactions data from Freddie Mac and Fannie Mae. The comparison can be done for the periods 1993 to 1995 and 1996 to 1998 since the 1992, 1995, and 1998 SCFs provide information on the type of property in which the respondent households reside. ${ }^{16}$

The resulting capital gains based on the SCF household surveys are 5.3 percent per year from 1993 to 1995 and 5.9 percent per year from 1996 to 1998. The actual capital gains based on OFHEO data are only 2.6 percent per year from 1993 to 1995 and 4.3 percent per year from 1996 to 1998. This suggests that household self-reported estimates of the market value of their homes, if anything, leads to higher capital gain estimates. See all also Michael Collins et al. (2001) for a summary of the literature on homeowners estimates of the value of their homes. This literature finds only small valuation biases of different sign in different surveys. If self-reported private equity values exhibit a similar bias, it is likely our private equity return estimates overstate the true returns.

Another possibility is that households simply employ a static valuation model or "rule of thumb" to estimate their private equity value. For example, households may simply report the book value of their private equity holdings if they find it difficult to estimate market values. This would tend to understate returns in periods when the market-to-book ratio is increasing. However, in the 1989 survey, both market and book values are reported for the three firms in which the household has its largest actively managed equity share. The aggregate market-to-book ratio for proprietorships and partnerships is 1.74 and for $\mathrm{S}$ and $\mathrm{C}$ corporations is 1.24 , indicating that households are distinguishing between market and book values. Furthermore, the dispersion of household market-to-book ratios is substantial. The lower quartile of reported market-to-book ratios for proprietorships and partnerships is 0.95, while the median and upper quartile is 1.25 and 4.58, respectively. The lower quartile, median, and upper quartile for $\mathrm{S}$ and $\mathrm{C}$ corporations is $1,1.47$, and 6.41, respectively (leaving out households with zero book equity values). This indicates that

\footnotetext{
${ }^{16}$ One adjustment to the SCF data is needed. The value of new homes sold in between survey years enter the current SCF calculation in the same way as new firms created between survey years affected the calculation of the return to private equity. We therefore subtract an estimate of the value of new single family houses sold between survey years from the end of period SCF value of single family houses to obtain the correct capital gain. The estimate of the value of new single family houses is obtained from the U.S. Bureau of the Census. The capital gain for the period 1993 to 1995 is thus calculated as, ((SCF based 1995 total value of single family houses - U.S. Bureau of Census estimate of the value of new single family houses sold in 1993, 1994, and 1995)/(SCF based 1992 total value of single family houses $))^{(1 / 3)}$. Similarly for the 1996 to 1998 period.
} 
the majority of households are not simply reporting book values.

Finally, the private and public equity returns seem to move together over the three subperiods. Moreover, in the next subsection, we show that the two return series are highly correlated over the longer time period from 1952 to 1999.

\section{E. Another Data Source - the FFA/NIPA}

For further robustness, Table 4 also computes the return to private equity using data from the FFA/NIPA. The national accounts do not rely on survey information and are therefore free of potential household reporting biases and provide an independent check on our return estimates.

The FFA market equity estimates for proprietors and partnerships and $\mathrm{S}$ and $\mathrm{C}$ corporations are described in Section III.A. For the income component of returns, we adjust NIPA P\&P income in three ways. First, we change the adjustment for misreporting of profits on income tax returns to be 75 percent in each year from 1959 onward, implying that for every $\$ 1$ of profits reported to the IRS, adjusted profits are $\$ 1.75 .{ }^{17}$ This differs from the income underreporting adjustment made in NIPA, which fluctuates dramatically over time, from a low of 33 percent in 1959 to a high of 200 percent in 1982, see NIPA Table 8.23. While some fluctuations in income underreporting to the IRS is possible, this level of volatility seems implausible. Appendix $\mathrm{C}$ discusses the main source of information about income underreporting on tax returns, which are studies performed by the IRS under the Tax Compliance Measurement Program (TCMP). However, given the substantial uncertainty about the actual amount of income underreporting to the IRS in any given year, we employ a constant 75 percent adjustment each year. Our resulting returns for P\&P over the 1952 to 1999 period are very similar to what would be obtained using the same income underreporting adjustment as NIPA. Second, we subtract the capital consumption adjustment included in NIPA profits from earnings to get a measure of the actual profit flows to proprietors. To the extent that tax laws allow for different depreciation than the true economic depreciation, the difference will show up in the capital gain component of returns. Third, as a measure of actual retained earnings in the firm, we add capital expenditures plus net acquisition of financial assets minus net increase in liabilities (excluding "proprietor net investment"). This measures the amount owners must have invested to cover firm investment, whether from profits or additional paid in funds. The ratio of retained earnings to profits averages 23 percent for the 1952 to 1999 sample and 25 percent for 1989 to 1998.

\footnotetext{
${ }^{17}$ The NIPA data do not rely on IRS data prior to 1959, see Parker (1984).
} 
For private $\mathrm{S}$ and $\mathrm{C}$ corporations, we estimate dividend income as total dividends paid by all corporations (from NIPA) minus dividends paid by public corporations (from CRSP). ${ }^{18}$ In addition, we add 20 percent of the NIPA income underreporting adjustment made to total corporate profits. ${ }^{19}$ Appendix $\mathrm{C}$ details the exact tables and line items we use from the FFA/NIPA.

Using these equity and dividend series, Panel B of Table 4 reports an average annual return to private equity of 4.1, 16.7, and 22.4 percent from 1990 to 1992, 1993 to 1995, and 1996 to 1998, respectively, using an estate multiplier of 200 for $\mathrm{S}$ and $\mathrm{C}$ corporations. When employing an estate multiplier of 300 , the returns drop to $2.1,14.7$, and 19.4, respectively. These returns subtract out the average labor adjustment from the SCF (6.5 percent per year for $\mathrm{P} \& \mathrm{P}$ and 1.2 percent for S\&C), and should be compared to line 4 in Panel A for the SCF. The FFA/NIPA returns are slightly lower in the first subperiod, but slightly higher in the latter two periods. Compared to the public returns, the private FFA/NIPA returns are lower in two of the three subperiods. We do not adjust for firm entry or exit in the FFA/NIPA (since an entry adjustment is not feasible), but the SCF numbers suggest that the total effect of this is small (compare lines 4 and 9 in Table 4).

Separating out $\mathrm{P} \& \mathrm{P}$ returns from $\mathrm{S} \& \mathrm{C}$, it is again the $\mathrm{P} \& \mathrm{P}$ returns that are the lowest. However, even the S\&C returns using an estate multiplier of 200 (our highest return estimates) do not consistently outperform the public index.

An advantage of the FFA/NIPA data is that it is available since 1952, allowing a comparison of private and public equity returns over a longer time period. Since public equity experienced large growth over the 1990's, it is useful to examine private and public equity returns over a longer period. The drawback from the longer analysis is that we can only examine proprietors and partnerships (as discussed earlier). Again, we do not account for firm entry and exit in this calculation, but comparing lines 5 and 10 in Table 4, the SCF numbers suggest that these effects largely cancel out for proprietors and partnerships. The SCF numbers omit the effects of new equity to existing firms and equity recovered by discontinued firms. We argued that these effects are small and likely

\footnotetext{
${ }^{18}$ Since both the NIPA and CRSP dividend series do not adjust for intercorporate holdings, our measure of private $\mathrm{S}$ and $\mathrm{C}$ dividends will also double count dividends due to intercorporate holdings. However, since our measure of equity also double counts intercorporate holdings, our return estimates should not be biased.

${ }^{19}$ Based on SCF market value of private S and C corporations, these corporations account for between 24 and 51 percent of all corporate equity. Since part of the hidden income is likely retained in the firm (and thus shows up as capital gains), we add only 20 percent of the NIPA corporate income underreporting adjustment to private $\mathrm{S}$ and $\mathrm{C}$ profits. The FFA income underreporting adjustment for corporations is around 15 percent during the 1989 to 1998 period. For large $\mathrm{C}$ corporations (assets greater than $\$ 10$ million with no distinction between public and private C corporations), the IRS TCMP does not report recommended changes in income, only the changes in taxes. The results based on audit yields imply recommended dollar tax increases of 21.4 percent using 1985 data. With progressive taxes the underlying income changes will be smaller.
} 
cancel out for all private equity. This is likely the case for proprietors and partnerships as well. ${ }^{20}$

Table 5 Panel A reports the arithmetic and geometric average annual returns and standard deviation to private equity for P\&P over the 1952 to 1999 time period. Panel B reports the average public equity return and standard deviation over the same period. The private and public equity returns are similar. Moreover, when comparing the private returns to the smallest decile of CRSP stocks, the public equity returns significantly outperform private equity over the longer period.

Since the $\mathrm{P} \& \mathrm{P}$ equity contains tangible assets at market value, but does not capture the value of intangibles, it is useful to compare its return to book equity returns in the public market. Using Compustat data on public book values (which is only available from 1963 on and is defined as in Eugene F. Fama and Kenneth R. French (1993) to be book value of stockholder's equity plus balance sheet deferred taxes and investment tax credit minus the book value of preferred stock), we compare public value-weighted book equity returns to P\&P returns from the FFA from 1963 to 1999. A comparison with public book equity returns also abstracts from public market realizations, which Eugene F. Fama and Kenneth R. French (2001) argue has inflated estimates of the public equity premium over the last half century. The book equity returns on public equity are about 2 to 3 percent per year higher than the returns to equity in private P\&Ps.

In sum, these numbers based on the FFA/NIPA are reassuring, confirming our previous conclusion that the returns to private and public equity are similar.

\section{F. The Risk of Private Equity}

Is the private market riskier in aggregate than the public market? This is hard to evaluate with the available data. The P\&P equity in the FFA is a "mix" of book and market equity since it captures tangible assets at market value but does not capture intangibles. As reported in Table 5, the standard deviation of the $\mathrm{P} \& \mathrm{P}$ equity return series is about twice that of the public equity book return series and a bit less than half that of the public market value return series. Figure 1 plots the FFA/NIPA return series of private proprietors and partnerships and the book equity returns series for public firms. The series exhibit a strong correlation of 0.70 over the 1963 to 1999 period, suggesting that it may be more relevant to compare the $\mathrm{P} \& \mathrm{P}$ return volatility to the public equity book return volatility. Finally, to gauge the riskiness of market equity returns, note that the annual

\footnotetext{
${ }^{20}$ In the $1993 \mathrm{NSSBF}$, "new equity to existing P\&P firms" is 10 billion annually. We estimate that sales/liquidations amount to 35 billion (likely an upper bound). If half of this is attributed to proprietor and partnerships, the net effect is $17.5-10=7.5$ billion per year. This is about 0.4 percent of P\&P equity in the $1992 \mathrm{FFA}$, implying only a small downward bias in our return estimates.
} 
standard deviation of the smallest decile of public firm returns is 30 to 40 percent. A portfolio of even smaller private firms is likely to be at least this volatile. More importantly, since entrepreneurs typically own equity in a single private firm, the risk faced by the average entrepreneur is much higher still.

In the next section, we analyze firm level entrepreneurial risk and returns. We argue that the risk return trade off faced by the typical entrepreneur is much worse than that of the private equity index, and, therefore, also likely to be much worse than that of the public equity index.

\section{The Distribution of Returns Across Private Firms}

Since most entrepreneurs own equity in a single private firm for which they have an active management interest, we are interested in characterizing the distribution of returns across individual entrepreneurs. In this section, we first discuss the conditions under which the index return will be a good estimate of the average individual return. We argue that the average geometric (buy and hold) return in the cross-section of firms is likely substantially lower than the geometric average return of the private equity index. In order to document the dramatic amounts of idiosyncratic private firm risk, we then examine the returns to an individual entrepreneur by considering firm survival rates and the distribution of individual entrepreneur returns conditional on firm survival.

\section{A. When Are Aggregate Returns a Good Measure of the Returns to the Av- erage Single Private Firm?}

The documented poor diversification of private equity holdings suggests that the typical investor cares about the return to investing in a single firm, rather than an index of private equity. Unfortunately, available data do not allow us to directly compute the average geometric return across firms. We only have estimates of firm survival rates and firm level returns conditional on survival, but do not have firm level information about the return to firms who were discontinued (bankrupt, sold, etc.). To our knowledge, no comprehensive data of this sort exists. In this subsection we argue, however, that the index return we calculate most likely overstates the average of the returns across individual entrepreneurs.

Data from the SCF indicate that the typical investment horizon of an entrepreneur is long. The average surviving entrepreneur has owned his firm for about 10 years at the time of the survey, implying a typical horizon of at least 10 years. Illiquidity of private equity is one factor contributing to long holding periods. Long holding periods suggest that entrepreneurs are primarily concerned 
with the buy and hold return of their investment. For example, if returns consisted only of capital gains, and horizons were exogenous, entrepreneurs would care about the geometric return over their holding period. Moreover, the theoretical models of Heaton and Lucas (2001), Brennan and Torous (1999), and Benartzi (2001) (motivated in the introduction) all focus on the geometric buy-andhold returns of individuals. Consequently, we focus on whether the geometric return on the index is an upward biased estimate of the average geometric return across individuals. To the extent that returns have a stochastic dividend component, the entrepreneur will care not only about the properties of the geometric return but also about other features of the return path. In this case, determining whether the private equity index returns and poor diversification documented earlier constitutes a puzzle requires further theoretical work. We leave this for future study and focus here on whether the average geometric return across firms is lower than the geometric value weighted return. We argue that this is likely to be the case, strengthening the conclusion that the returns to private equity are surprisingly low.

The key feature of the return distribution which leads to the geometric index return being an upward biased estimate of the average geometric return across firms is the presence of idiosyncratic firm risk. To illustrate this, consider first the case with no idiosyncratic risk. Suppose the typical firm lives for $N$ periods, where the initial investment is $\$ 1$, and the firm grows exponentially to be worth $\$ K$ at date $N$. The setting is one with "overlapping firm generations", in which one firm is born each year and one firm is sold in each period at age $N$. Thus, $N$ is the holding period of the founder. To simplify the calculations assume that private firms are sold to public firms after $N$ periods. The geometric return obtained by each founder is simply $K^{1 / N}$, which is therefore also the average geometric return across entrepreneurs. The geometric index return, $1+r$ geometric, index, is the return to buying all $N$ private firms in existence at date $t$ (the newborn firm, the 1 year old firm, ...., up to the $N-1$ year old firm) and holding these firms until date $t+1 .{ }^{21}$ The denominator in the calculation of $1+r$ geometric, index is the total purchase price for the $N$ firms at date $t$. The numerator is the total value of these $N$ firms at date $t+1$, including the $K$ obtained from selling the oldest firm to a public company.

Under this scenario of gradual firm growth, the geometric index return and the average geometric return across firms are identical (and both constant over time):

\footnotetext{
${ }^{21}$ With the adjustment to date $t+1$ value for the newborn firm at date $t+1$ (as in the index calculations above) this firm will not affect our calculation.
} 


$$
\begin{array}{ccc} 
& \frac{1+r^{\text {average, geometric }}}{\text { Gradual Growth: }} \quad \frac{1+r \text { geometric, index }}{} \\
K^{1 / N} & \frac{K^{1 / N}+K^{2 / N}+\ldots+K}{1+K^{1 / N}+K^{2 / N}+\ldots+K^{(N-1) / N}}=K^{1 / N}
\end{array}
$$

If growth is not gradual (and still with no idiosyncratic risk) the geometric index return will not be identical to the average geometric return across firms. In the case of early growth, the index return will understate the average geometric return across firms, while the opposite will be true under late growth. For example, if firm value grows to $K$ after only one period and then stays constant (early growth), the returns are:

$$
\begin{aligned}
& \underline{1+r \text { average, geometric }} \underline{1+r \text { geometric, index }} \\
& \text { Early Growth: } \quad K^{1 / N} \quad \frac{N K}{1+(N-1) K}<K^{1 / N}
\end{aligned}
$$

On the other hand, if firm value stays constant at $\$ 1$ until date $N-1$, and then jumps to $\$ K$ at date $N$ (late growth), the returns are:

$$
\underline{1+r^{\text {average, geometric }}} \underline{1+r^{\text {geometric}, \text { index }}}
$$

$$
\text { Late Growth: } \quad K^{1 / N} \quad \frac{(N-1)+K}{N}>K^{1 / N}
$$

Without idiosyncratic risk, the bias in the index return depends on the growth profile of firms. However, when adding idiosyncratic risk, the geometric index return is likely to be lower than the average geometric return across firms, even in cases with substantial early growth. Consider augmenting the above setting as follows. Suppose firms face a constant bankruptcy probability over time and that equity investors in bankrupt firms lose half of their investment in the bankruptcy state. The probability of bankruptcy, $p$, is calibrated to a 35 percent survival rate of firms within the first 10 years of life. Furthermore, in each period, surviving firms face a two point distribution of returns. The two points of this distribution are chosen to generate pre-chosen values for the mean and standard deviation of a firm's return. To capture early growth, assume the mean return conditional on survival declines with firm age according to the formula $\mu_{t}=1+0.4 /(b t)$, where $b=0.3$ to generate a strong decline in mean returns over firm life (e.g., from 40 percent per year at age 1 to 8 percent per year at age 5 ). If volatility $\sigma_{t}$ is constant at 30 percent per year (likely a fairly low number for the typical private firm given that the annual standard deviation of a typical single public firm's equity return is 50 to 60 percent according to John Campbell et al. (2001)), and $N=20$, then the geometric index return is 10.9 percent per year while the average geometric return across firms is 4.7 percent per year. As an alternative scenario, if volatility is allowed to decline with firm age such that the Sharpe ratio $\left(\mu_{t} / \sigma_{t}\right)$ is constant over a firm's life (equal to 0.3), 
then the geometric index return is 10.9 percent per year while the average geometric return across firms is as low as -11.7 percent per year. ${ }^{22}$

These calculations illustrate how even a low level of idiosyncratic risk will bias the index return upward, even with early firm growth. The difference between the index return and the average individual firm return would be even larger with gradual or late growth. Although we do not have adequate firm-level information to directly determine whether early, gradual, or late growth occurs, the fact that risk seems to decline with age suggests that early growth and early risk are probably most consistent with the data.

While the calculations are admittedly simple, they illustrate that our geometric index return is likely to be a substantially upward biased estimate of the typical geometric return to a single firm. Hence, the true return to a poorly diversified individual entrepreneur is likely much lower than our previous calculations suggest. We now turn to documenting the amount of idiosyncratic risk of a single private firm.

\section{B. Private Firm Survival Rates}

Certainly, a large part of the risk associated with starting a new business is the risk of failure, as opposed to a risky distribution of returns conditional on survival. In order to gauge this, we appeal to outside evidence on firm survival rates. Timothy Dunne et al. (1988) construct firm survival rates based on the 1967, 1972, 1977, and 1982 Census of Manufacturers, and find that on average 61.5 percent of firms exit in the five years following the first census in which they were observed. On average, 79.6 percent of firms exit within ten years. Popkin and Kirchhoff (1991) analyze survival rates by age of business from 1976 to 1986, using the United States Establishment Longitudinal Microdata file (USELM) which is based on Dun and Bradstreet's marketing file. They estimate that the two year survival rate of firms who were less than two years old in 1976 is 76.9 percent, and the ten year survival rate is 34.4 percent. Survival rates increase with initial firm age. Firms who were between 10 and 19 years old had a two year survival rate of 73.9 percent and a ten year survival rate of 48.8 percent.

It is difficult to evaluate how much business owners lose when their business is discontinued. Data provided by the U.S. Small Business Administration (2000) document that the average annual number of firm bankruptcies over the 1990 to 1997 period was 59,393 (source: The Administrative

\footnotetext{
${ }^{22}$ Several empirical facts suggest the presence of "early risk". Firstly, bankruptcy rates decline with firm age (Joel Popkin and Bruce A. Kirchoff (1991)). Secondly, the cross-sectional standard deviation of average geometric returns across surviving firms is declining with holding period in the SCF.
} 
Office of the U.S. Courts). The number of bankruptcies is somewhat lower than the average number of business failures of 78,711 over this period (source: Dun and Bradstreet Corporation). A business failure is defined as an enterprise that ceases operation with a loss to one or more creditors. The average number of failures constitute 15.3 percent of the average total number of firm terminations, which was 515,273 over the same time period. Owners in failed companies probably lose all of their initial equity investment (since they discontinue with debt outstanding). Entrepreneurs can, in fact, lose more than their equity investment since firm debt is often backed by personal collateral (typically home equity). Assuming they lose all of their equity in failed firms, combining the survival rates with the share of discontinued firms who fail, the founder of a new private company faces a $(1-0.344) \times 0.153 \times 100=10.0$ percent risk of losing all of his/her investment within the first 10 years.

For the remainder of discontinued firms it is difficult to evaluate how much of the initial equity investment by owners has been lost, if any. Some firms may be discontinued with a full or partial equity investment loss due to poor future prospects. Others are successful, and may be sold to new owners or "cashed out." The number of firm sales/takeovers is quite low. In the 1993 NSSBF about 70,000 firms were acquired within the last two years (two years to account for possible lag in introduction to the Dun and Bradstreet database on which the NSSBF sample is based). This implies that approximately 350,000 (or about 70 percent of) terminated firms liquidated. It is likely that entrepreneurs lose at least some, if not all, of their investment upon liquidation. Clearly, failure/liquidation poses a great risk.

\section{Entrepreneur Level Returns Conditional on Survival}

The rest of this section focuses on the conditional distribution of entrepreneurial returns to document that substantial idiosyncratic risk exists even conditional on survival. Using data on individual household investment in private equity from the SCF, we calculate the distribution across households of returns since they founded/acquired a private firm. We examine those private companies in which the household has its largest actively managed equity position. The following information is available from the SCF: the year in which the firm was founded/acquired, firm profits in the year before the survey interview, the market value of the ownership share in the interview year (estimated by the respondent), and the basis value for tax purposes of the current ownership share. We use the latter as an estimate of the initial value of the entrepreneur's equity investment.

We estimate the geometric average annual capital gain over the period since the firm was founded/acquired. Assuming the current profit to equity ratio is representative of those in previous 
years, we also construct an estimate of the income stream to the household from the investment. These returns represent the price appreciation and income received from the initial investment date to the time of the survey. We are not able to construct estimates of the return obtained through the full period of ownership, of course, since households may keep their ownership share in the company for many years after the survey. We are also not able to construct return estimates for household investments that did not survive. Hence, we emphasize that the distribution of returns we calculate is conditional on survival, and does not represent the unconditional distribution of returns.

We plot in Figure 2 the distribution of returns from private equity investment. The graphs pertain to the distribution of household returns from the 1989 SCF. Other survey years were similar. $^{23}$

The first graph plots the histogram of average annual capital gains accrued across households over the period since the firm was founded/acquired. For each household, we compute the geometric average annual capital gain as

$$
\left(\frac{\text { Value at the time of the survey }}{\text { Value of original investment }}\right)^{1 /(\text { Years since founded/acquired })}-1 \text {. }
$$

The distribution of capital gains, conditional on survival, is wide. ${ }^{24}$ Using the 1989 survey, the median of the capital gain distribution is 6.9 percent per year, while the 1 st quartile is 0 and the 3rd quartile is 18.6 percent per year. As for the holding periods over which these annualized capital gains have been obtained, 43 percent of households had invested in private equity for 5 years or less at the time of the survey, 47.3 percent had invested for between 5 and 25 years, and 9.6 percent had invested for more than 25 years (averaged across all four survey years).

The second graph plots the histogram of earnings rates, defined as earnings in the year before the survey divided by the total market value of the firm. There is substantial variation in earnings rates, although most households report zero or positive earnings rates. The third graph in each panel plots the histogram of the geometric average returns households would have obtained had they invested their wealth in the CRSP index of all publicly traded equity over the same horizon as their private equity investment. For example, for an investor who held private equity in his

\footnotetext{
${ }^{23}$ We focus on households with initial investments of at least $\$ 1,000$ (1983 dollars using the CPI for all urban consumers). This implies dropping about 5 percent of the entrepreneur households. All graphs employ SCF weights.

${ }^{24}$ We plot households who lost all of their initial capital but still say they are in business at -100 percent in this figure. These households are not included in the subsequent graphs since it is not possible to define profit/equity for companies with zero equity.
} 
company for 30 years at the time of the 1989 survey, we compute the geometric average annual return to investing in the CRSP index over those same 30 years (i.e., from 1959 to 1989). As shown in the graph, the distribution of returns on a diversified public equity index over the same investment horizon is tight, with a minimum return of 5.6 percent per year and a maximum return of 19.9 percent per year.

The final graph combines the capital gain and income components to construct a total return, where we assume earnings rates are constant over time and equal those in the interview year, and that (for simplicity) 30 percent of profits are retained in the firm across all firm types. ${ }^{25}$ We then subtract from this total return the return the household could have obtained by investing in the CRSP index over the same period. This essentially combines the first three plots into one.

Even though this distribution is conditional on survival, around 30 percent of households would have been better off investing in the CRSP index rather than their own company. Moreover, there is substantial variation in the excess returns to private over public equity investment, even conditional on survival. The excess return distribution is highly skewed. While the median excess return is 18.2 percent per year, the average excess return is 139.6 percent per year due to a fairly small fraction of households with very large annualized excess returns. These high mean/median excess returns are to a large extent due to households with small initial investments. When households are weighted by the size of their initial investment, the median excess return is -2.0 percent per year while the mean excess return is 24.4 percent.

\section{Conditional versus Unconditional Mean and Variance}

Finally, our conclusions that entrepreneurial returns appear unattractive are based on an estimate of the unconditional distribution of private equity returns. That is, for a randomly chosen entrepreneur, investment in private equity seems like a bad deal. However, entrepreneurs may have superior information about their firm's prospects. In this case, the conditional variance of returns to each entrepreneur may be much lower than suggested by the poor diversification and high firm level risk. Thus, for some individuals entering entrepreneurship may be a very good deal. However, if entrepreneurship is attractive for some entrepreneurs, then it must be even less attractive for other entrepreneurs than what our return estimates suggest. Hence, if the low returns appear puzzling on average, they must be even more puzzling for a segment of the entrepreneur population.

\footnotetext{
${ }^{25}$ Since we wish to have uniform assumptions across firm types, and since our previous calculations employed 40 percent retention for $\mathrm{C}$ corporations and 20 percent for all other firm types, a 30 percent retention rate is used.
} 


\section{Why Do People Become Entrepreneurs?}

In this section, we briefly discuss possible explanations for why private equity investors willingly invest in concentrated private equity portfolios despite the seemingly poor risk-return tradeoff.

\section{A. Optimal Contracting and the Ability to Diversify}

Concentrated private equity investments could be motivated by issues of moral hazard or asymmetric information. Institutional and governmental monitoring is also far less prevalent in the private market, making assignment of control rights of the firm even more critical. However, this cannot explain why individuals enter into entrepreneurship initially, given the poor risk-return tradeoff.

\section{B. Why Are Entrepreneurs Willing to Participate in the First Place?}

We consider five possible explanations for entry into entrepreneurship, despite the poor risk-return trade-off of existing entrepreneurs: high entrepreneur risk tolerance, large additional pecuniary benefits, non-pecuniary benefits, a preference for skewness, and overoptimism and misperceived risk.

\section{B.1 Risk Tolerance}

If entrepreneurs have very low risk aversion, then disutility from poor diversification may be small and the returns to private equity need not be higher than those of public equity. Gentry and Hubbard (2000) compare the composition of entrepreneur portfolios to those of non-entrepreneurs using the $1989 \mathrm{SCF}$. They find that (apart from the sizeable 41 percent investment in the private equity of their own firm), the rest of entrepreneurs' portfolios are quite similar to non-entrepreneurs, even for those in the top 5 percent of the wealth distribution. Since entrepreneurs do not invest the remainder of their wealth any more conservatively than non-entrepreneurs, they may be more risk tolerant. However, it is possible that private equity holders might be expected to hold larger shares of their remaining wealth in public equity. This is suggested by the results of Heaton and Lucas (2001) and is due to the fact that private equity income provides not only "background risk" but also positive income flow on average. ${ }^{26}$

\footnotetext{
${ }^{26}$ Furthermore, even the wealthiest entrepreneurs appear far from risk neutral. A recent article in the Wall Street Journal ("Your Money Matters. Hedging a Single Stock Has Ups, Downs", by Ruth Simon, February 2, 2000) cites the rising popularity of hedging strategies offered by investment firms to reduce exposure to own company stock performance for top executives (as many as a couple thousand such strategies are executed each year). This suggests that executives do care about the volatility of their own company stock holdings, and take steps to reduce their exposure to the firm. One of the more notable participants in these strategies is Ted Turner, despite his more than $\$ 9$ billion wealth (at the time of the article).
} 


\section{B.2 Other Pecuniary Benefits and Costs}

Salaries derived from private companies are already accounted for in our return calculations. To assess the benefits derived from possible perquisite taking, we compute how large these benefits would have to be to provide a 10 percent per year return premium in private equity over public equity. This amounts to 143 percent of total annual household income (or $\$ 460,000$ ) for the median entrepreneur (using data from the $1998 \mathrm{SCF}$, focusing on entrepreneurs with at least $\$ 5,000$ of private equity holdings and weighting households by the size of their holdings). This seems high given that salaries and unreported income from tax evasion are already accounted for.

In addition, we should consider the fact that investors compare asset returns after personal taxes. Previously, we used survey data or NIPA data with an adjustment for income underreporting on tax returns to produce more accurate pre-personal tax returns, comparable to the returns from CRSP. It remains to consider whether personal taxes differ between private and public equity holders. Certainly, since entrepreneurs save taxes on income they hide from the IRS, their effective tax rate is lower than the statutory rate. This effect is likely to be small. ${ }^{27}$ Furthermore, a substantial fraction of public equity is held in tax advantaged accounts, reducing the effective tax rates paid on public equity.

On the cost side, at least 25 billion dollars in profits in each of the SCF years pertain to households who report a zero market value and a zero tax basis for their equity share. It may be more reasonable to exclude these households from our analysis, which would lower our return estimates by about 0.5 percent per year. A large fraction of these profits are in partnerships. The zero equity value may simply reflect the fact that equity shares are not tradable in these firms, but rather are payments for labor input to employees who make partner.

\section{B.3 Nonpecuniary Benefits}

In addition, nonpecuniary benefits derived from entrepreneurship may explain the concentrated equity holdings. Over 21 percent of survey respondents in the 1992 Economic Census Characteristics of Business Owners stated being their own boss as the main reason for starting the firm, as opposed to having a primary or secondary source of income as the main reason. Other studies have also identified the flexibility and autonomy of self-employment as a major nonpecuniary benefit

\footnotetext{
${ }^{27}$ For example, if the statutory personal tax rate is 30 percent, and 30 percent of income is sheltered from tax authorities, the effective tax rate is 21 percent. This increases the income component of after-tax returns of private companies relative to public companies, assuming the latter does not hide income, by 9 percent (e.g., from 10 percent per year to 10.9 percent).
} 
(see David G. Blanchflower and Andrew J. Oswald (1992)). Indeed, Hamilton (2000) interprets his results for the median entrepreneur as evidence of large nonpecuniary benefits.

Using the calculation from above, a 10 percent (of private equity investment) nonpecuniary benefit would have to amount to 143 percent of total annual income or $\$ 460,000$. While a substantial amount, this may not be unreasonable. Certainly, many financial economists willingly give up substantial amounts by choosing to remain in academia, where the academic lifestyle may be considered a nonpecuniary benefit.

\section{B.4 Preference for Skewness}

Rather than try to augment the first moment of the return distribution of private equity through additional pecuniary or nonpecuniary benefits, a motivation for entrepreneurship may lie in higher moments of the distribution. For instance, Figure 2 shows that the distribution of entrepreneurial returns is highly skewed with a fat right tail. If entrepreneurs have a preference for skewness, then they may be willing to accept a lower mean return despite the high variance. A preference for skewness could explain the result in Gentry and Hubbard (2000) that progressive marginal tax rates discourages entry into entrepreneurship.

Alan Kraus and Robert Litzenberger (1979) and Campbell R. Harvey and Akhtar Siddique (2000) argue that investors have a strong skewness preference. However, skewness in returns can also be obtained more easily through the options market or various trading strategies in public markets. Hence, the skewness of private equity returns may not be the only attribute attracting investors.

\section{B.5 Overoptimism and Misperceived Risk}

Finally, entrepreneurs may behave in a manner that is not perfectly rational. For instance, they may be overly optimistic about the firm's mean prospects or they may irrationally believe that having control of the firm lowers risk.

We showed previously that the average return, conditional on survival, from private equity is about 24 percent greater than the public market return. Hence, if entrepreneurs simply believe their probability of survival is sufficiently high, then the distribution of future returns would look very attractive. Survey evidence of entrepreneurs is consistent with this notion. Arnold C. Cooper et al. (1988) find that 68 percent of entrepreneurs think that the odds of their business succeeding is better than the odds for another business like theirs; only 5 percent think their odds are worse. 
In addition, a third of entrepreneurs believe their probability of success (e.g., surviving) is 1, and 72 percent of entrepreneurs think their probability of success is at least 0.80. J. Edward Russo and Paul J. H. Schoemaker (1992) find that managers are dramatically overconfident. ${ }^{28}$

Most likely, it is some combination of all five explanations that contribute to entrepreneurial activity. Quantifying the impact each has on the propensity to become an entrepreneur, as well as on subsequent returns, is an interesting issue left for future research.

\section{Concluding Remarks (Is There a Puzzle?)}

We find that the majority of household investment in private companies is concentrated in a single, risky, privately held firm in which the household has an active management interest. Despite the risks these investors face in taking on large amounts of idiosyncratic risk, the returns to private equity are surprisingly low. We conduct the first comprehensive study of the unconditional returns to all nonpublicly traded equity. Controlling for the labor component of returns, adjusting for entry and exit of firm equity over time (as best possible), and addressing issues related to potentially distorted estimates of market values and firm profits (e.g., due to tax evasion motives) we find that the average return to private equity is similar to that of public equity. Given the large equity premium demanded by investors in public markets, it seems surprising that individuals are willing to invest so heavily in a single private firm which offers a far worse risk-return tradeoff.

We recognize that a precise measure of the mean return to private equity is extremely difficult to obtain. Expected returns are notoriously difficult to estimate and our estimates are based on relatively short sample periods (10 years for the SCF and 47 years for the FFA/NIPA). This difficulty is exacerbated when using fairly imprecise data on estimates of private firm values and profits. Nevertheless, the estimated realized returns to private equity are quite highly correlated with public equity returns, indicating it is less likely that the realized returns represent an abnormal draw for one of the two markets only or simply measurement error in our data. Moreover, we argued earlier that it is unlikely that the private equity mean return exceeds the public equity mean return by 10 percent per year (as theory suggests it should). Our findings for the private equity market present a challenge to theories seeking to explain the size of the equity premium in public markets within a homogeneous agent framework.

Whether or not our results constitute a puzzle remains an open question. On the empirical side, more information about the amount of equity recovered in liquidated firms would enable a more

\footnotetext{
${ }^{28}$ Antonio Bernardo and Ivo Welch (1998) argue why individuals remain overconfident in an entrepreneurial setting.
} 
precise estimate of the unconditional returns to private equity and the cross-sectional distribution of those returns. It would also be interesting to obtain a longer return series for $\mathrm{S}$ and $\mathrm{C}$ corporations to determine if the fact that $\mathrm{S}$ and $\mathrm{C}$ corporations outperform proprietors and partnerships is robust to other sample periods outside of the 1990's. On the theory side, models that capture the correlation of human and financial capital returns and allow for consumption by the entrepreneur before the terminal date are needed.

Finally, distinguishing among other motives for entrepreneurship (i.e., private benefits of control, preferences for skewness, and misperceptions of the probability of failure) may have important policy implications. For example, if entrepreneurs are enticed by small probabilities of very large returns, high tax rates for high income individuals could have strong adverse growth effects. On the other hand, if many entrepreneurs enter business with overoptimistic expectations, government educational efforts (as opposed to government subsidized small business loans) may be warranted. 


\section{Appendix A: Estimating the Value of Equity in Private S and C Corporations Based on Estate Tax Returns}

To obtain an estimate of the value of equity in private $\mathrm{S}$ and $\mathrm{C}$ corporations which is independent of the SCF equity numbers, we follow a method used by the IRS to estimate wealth based on estate tax returns. The approach is described in Section III.A. This appendix provides evidence that owners of private equity have lower mortality than others at the same age and with similar wealth. Thus, a multiplier higher than that used by the IRS should be used for this category of wealth.

Since most private equity is owned by households with active management interests, it is unlikely that holders of private equity have the same mortality rates as others at the same age and with similar wealth (as is assumed in the IRS multiplier). Entrepreneurs are likely to sell off their private businesses when their health deteriorates, making active management difficult. Consequently, a smaller percentage of private equity (than of other wealth components) shows up on estate tax returns for a given year.

Two measures of respondent health are available in the SCF to support this. Question X6030 asks, "Would you say your health is excellent, good, fair, or poor?" and question X7381 asks "About how old do you think you will live to be?" Responses to the first question are available for the 1989, 1992, 1995, and 1998 surveys and for the second for 1995 and 1998. Merging the data across years, and restricting attention to households with assets greater than $\$ 600,000$, we find that the percent of household heads reporting to be in poor health (for couples the respondent is the male) is 2.3 percent for non-business owners and 0.8 percent for owners of equity in private $\mathrm{S}$ and C corporations, using SCF weights and further weighting by amount of private equity owned. This ratio (2.3/0.8) equals 2.9. In addition, the percent of households expecting to live 5 (10) years or less is 3.9 (10.8) percent for non-business owners and 1.5 (5.2) percent for owners of private $\mathrm{S}$ and $\mathrm{C}$ corporation equity, corresponding to a ratio of 2.6 (2.1). Using the same weights as above, the owners of private $\mathrm{S}$ and $\mathrm{C}$ corporation equity are about three years younger than non-business owners. Taking this into account would lower the differential in mortality a bit.

In sum, if mortality is approximately linear in these measures of health, this suggests using a multiplier for $\mathrm{S}$ and $\mathrm{C}$ private equity which is between 2 to 3 times higher than that used for other wealth components. This is our motivation for employing multipliers of 200 and 300 to estimate the total value of $\mathrm{S}$ and $\mathrm{C}$ equity based on estate tax returns. 


\section{Appendix B: Estimating the Value of Missing Mergers and Acqui- sitions in the SDC Database}

For each deal in the SDC database with missing price information, we search for data on the transaction to indicate its size. We found four data items with broader coverage than deal value. These are: book value, property, plant and equipment, total assets, and number of employees of the target. We then take the deals with price data and run a cross-sectional regression of all deal values on a constant and each of these variables individually, as well as every combination of the variables, producing 15 sets of regression coefficients. This is done for each year and category separately. These regression coefficients are then used to predict the value of those deals with missing price information, but having at least one of the other variables. For example, if a deal is missing its value but has information on book value, we estimate its value by multiplying its book value times the coefficient estimated from the univariate regression of deal market value on book value for all deals with prices. If a deal has more than one data item, then we employ the corresponding multivariate regression coefficients from deals with prices. In other words, we use the regression coefficients from the appropriate combination of data items for which the deal has recorded information. This provides an estimate of the value of missing deals while taking into account the characteristics of such deals (i.e., that they are typically smaller). Finally, for those deals with missing value and no additional information on the other four data items, we simply assign the average of the estimated values of missing deals to these transactions. If anything, this is likely to overstate our numbers slightly. These estimated values are computed for each subcategory of merger and acquisition activity in the same manner and added to the value of deals with price information to produce a total or "scaled" value for each subcategory.

\section{Appendix C: Details on Numbers from the FFA and NIPA}

\section{C.1: Series Used in Our Calculations Based on the FFA and NIPA}

We calculate the baseline annual returns to proprietorships and partnerships $(\mathrm{P} \& \mathrm{P})$ as,

$$
\frac{P \& P(\text { Equity })_{t+1}+P \& P\left(\text { Profits }_{t+1}-C C A_{t+1}-R E_{t+1}+\Delta \text { Tax } a d j \cdot t+1_{\cdot}\right.}{P \& P\left(\text { Equity }_{t}\right.}
$$

where

1. $P \& P(E q u i t y)=(F F A$, Table btab100d, FL153080015) - (Value of 1 to 4 family rental properties not owned by corporations from the Bureau of Economic Analysis, fixed assets, 
detailed residential table).

2. $P \& P($ Profits $)=$ NIPA, Table 1.14 , line 9 .

3. $C C A=$ Capital consumption adjustment $=$ NIPA, Table 1.14 , line 12 plus line 16 .

4. $R E=$ Retained earnings $=(\mathrm{FFA}$, Table utab103d, FU116300005+FU113180005 $)+(\mathrm{FFA}$, Table utab104d, FU136000105+FU133180005).

5. $\Delta$ Tax adj. = Change in tax adjustment $=(0.75-$ NIPA P\&P tax adjustment percent used $) \times($ NIPA nonfarm $\mathrm{P} \& \mathrm{P}$ profits as reported to the IRS $)$, where NIPA P\&P tax adjustment percent used $=($ NIPA Table 8.23 line $2 /$ NIPA Table 8.23 line 1$)$ and NIPA nonfarm $\mathrm{P} \& \mathrm{P}$ profits are as reported to the IRS in NIPA Table 8.23 line 1.

We calculate the baseline annual returns to private $\mathrm{S} \& \mathrm{C}$ corporations as,

$$
\frac{S \& C^{\text {private }}(\text { Equity })_{t+1}+S \& C^{\text {all }}(\text { Div. })_{t+1}-S \& C^{\text {public }}(\text { Div. })_{t+1}+0.2\left(S \& C^{\text {all }}(\text { Tax adj. })_{t+1}\right)}{S \& C^{\text {private }}(\text { Equity })_{t}}
$$

where

1. $S \& C^{\text {private }}($ Equity) is estimated based on estate tax returns as described in Appendix A.

2. $S \& C^{\text {all }}($ Div. $)=$ NIPA dividends paid in cash or assets according to the IRS (NIPA, Table 8.25, line 29), plus Posttabulation amendments and revisions (NIPA, Table 8.25, line 30).

3. $S \& C^{\text {public }}($ Div. $)=$ dividends paid by companies listed on the NYSE, AMEX or NASDAQ calculated as the income return on the CRSP value weighted index times the total market value of NYSE, AMEX, and NASDAQ equity.

4. $S \& C^{a l l}($ Tax $a d j)=$. NIPA adjustment for misreporting on income tax returns, NIPA Table 8.25 , line 2 . See the text for the choice of the factor 0.2 .

Note that the FFA/NIPA frequently update their data. Our numbers are based on the latest available releases as of January 1, 2002.

Further adjustments for the labor component of profits and firm entry and exit are described in the text. 


\section{C.2: Tax Adjustments for Income Underreporting}

This subsection describes the findings of the IRS Tax Compliance Measurement Program (TCMP), which motivates the income underreporting adjustment for proprietors and partnerships in the FFA.

Every third year between 1973 and 1988 a sample of about 55,000 tax filers was subjected to extensive audits. The TCMP program has since been discontinued. TCMP audits differed from regular IRS audits in that only experienced IRS examiners were used, and in that examiners reviewed each item on the return line by line. The TCMP studies include information about all components of income, including income from proprietorships and partnerships. These studies were supplemented by separate studies of small corporation income tax returns for 1977 and 1980. For

large corporations, regular audit yields were extrapolated by the IRS based on a regression using averages of data for 1984, 1985, and 1986 to compute what audit yields would have been had all large corporations been audited. The results of the studies up to 1982 are summarized in IRS (1988).

According to the TCMP results income underreporting on tax returns is very prevalent, especially among small firms. For the category 'Other Sole Proprietorship' which refers to nonfarm sole proprietors with the exception of informal suppliers (baby sitters, street vendors, etc.) the ratio of detected non-reported income to tax payer reported income (accounting for both understated income and overstated expenses) is 0.219 for 1973, 0.229 for 1976, 0.299 for 1979, and 0.419 for 1982. For partnerships the ratios are 0.139 for 1973, 0.248 for 1976, and 0.277 for 1979 (the 1982 ratio is less reliable since reported partnership profits are close to zero in that year). The reason NIPA uses larger tax adjustments for proprietors and partnerships is that the TCMP conjectures that for every dollar detected in the TCMP audit an extra 2.34 dollars go undetected for proprietors (3.28 for partnerships). From what we were able to determine these 'multipliers' are based on very little information, and one wonders whether the IRS has an incentive to inflate these numbers. Nonetheless, to be conservative we use an income underreporting adjustment which reflects the use of such multipliers. 


\section{References}

Antoniewicz, Rochelle L., "A Comparison of the Household Sector from the Flow of Funds Accounts and the Survey of Consumer Finances", Working paper, Federal Reserve Board, 2000. Avery, Robert B., Gregory E. Elliehausen, and Arthur B. Kennickell, "Measuring Wealth with Survey Data: An Evaluation of the 1983 Survey of Consumer Finances," Review of Income and Wealth, 1988, 34, pp. 339-369.

Benartzi, Shlomo, "Excessive Extrapolation and the Allocation of 401(k) Accounts to Company Stock", forthcoming Journal of Finance, 2001.

Bernardo, Antonio, and Ivo Welch, "On the Evolution of Overconfidence and Entrepreneurs", Working paper, Anderson Graduate School of Management, UCLA, 1998.

Blanchflower, David G., and Andrew J. Oswald, "Entrepreneurship,Happiness and Supernormal Returns: Evidence From Britain and the US", NBER Working Paper, No. 4228, 1992.

Brennan, Michael J. and Walter N. Torous, "Individual Decision-Making and Investor Welfare", Economic Notes, 1999.

Bureau of Economic Analysis, 1989 - 1998. U.S. Department of Commerce. Washington, DC. Campbell, John and John Cochrane, "By Force of Habit: A Consumption-Based Explanation of Aggregate Stock Market Behavior", Journal of Political Economy, 1999, 107, pp. 205-251.

Campbell, John, Martin Lettau, Burton Malkiel, and Yexiao Xu, "Have Individual Stocks Become More Volatile? An Empirical Exploration of Idiosyncratic Risk", Journal of Finance, 2001, 56(1), pp. 1-44.

Collins, Michael, David Crowe, and Michael Carliner, "Examining Supply-Side Constraints to Low-Income Homeownership", Working paper, Joint Center for Housing Studies, Harvard University, 2001.

Cooper, Arnold C., Carolyn Y. Woo, and William C. Dunkelberg, "Entrepreneurs' Perceived Chances for Success", Journal of Business Venturing, 1988, 3, pp. 97-108. 
Dunne, Timothy, Mark J. Roberts, and Larry Samuelson, "Patterns of Firm Entry and Exit in U.S. Manufacturing Industries", Rand Journal of Economics, 1988, 19, pp. 495-515.

Fama, Eugene F., and Kenneth R. French, "Common Risk Factors in the Returns on Stocks and Bonds", Journal of Financial Economics, 1993, 53, pp. 427-465.

Fama, Eugene F., and Kenneth R. French, "The Equity Premium Puzzle", Working Paper, University of Chicago, 2001.

Flow of Funds Accounts, Fourth Quarter 1952 to 1999. Washington, DC: Board of Governors of the Federal Reserve System, 1952 to 1999.

Fenn, George W., Nellie Liang, and Stephen Prowse, "The Economics of the Private Equity Market", Working paper, Board of Governors of The Federal Reserve System, 1995, Staff Studies No. 168.

Gentry, William M., and R. Glenn Hubbard, "Entrepreneurship and Household Saving", NBER Working Paper \#7894, 2001.

Hamilton, Barton H., "Does Entrepreneurship Pay? An Empirical Analysis of the Returns to Self-Employment", Journal of Political Economy, 2000, 108, pp. 604-631.

Hansen, Lars P. and Kenneth J. Singleton, "Stochastic Consumption, Risk Aversion, and the Temporal Behavior of Asset Returns", Journal of Political Economy, 1982, 91(2), pp. 249-265. Harvey, Campbell R., and Akhtar Siddique, "Conditional Skewness in Asset Pricing Tests," Journal of Finance, 2000, 55, pp. 1263-1295.

Heaton, John and Deborah Lucas, "Portfolio Choice and Asset Prices: The Importance of Entrepreneurial Risk", Journal of Finance, 2000, 55, pp. 1163-1198.

Heaton, John and Deborah Lucas, "Capital Structure, Hurdle Rates, and Portfolio Choice Interactions in an Entrepreneurial Firm", Working paper, University of Chicago, 2001.

Internal Revenue Service, "Income Tax Compliance Research, Supporting Appendices to Publication 7285, Publication 1415, Washington, DC, 1988.

Johnson, Barry W., "Personal Wealth, 1995", SOI Bulletin, Winter 2000. 
Kennickell, Arthur B. and Martha Starr-McCluer, "Changes in Family Finances from 1989 to 1992: Evidence from the Survey of Consumer Finances", Federal Reserve Bulletin, 1994, 80, pp. 861-882.

Kennickell, Arthur B., Martha Starr-McCluer, and Annika E. Sunden, "Family Finances in the United States: Recent Evidence from the Survey of Consumer Finances", Federal Reserve Bulletin, 1997, 83, pp. 1-24.

Kennickell, Arthur B., Martha Starr-McCluer, and Brian J. Surette, "Recent Changes in U.S. Family Finances: Results from the 1998 Survey of Consumer Finances", Federal Reserve Bulletin, 2000, 86, pp. 1-29.

King, Carol S., and E. K. Ricketts, "Evaluation of the Use of Administrative Record Data in the Economic Censuses", Working paper, 1980.

Kraus, Alan and Robert Litzenberger, "Skewness Preference and the Valuation of Risk Assets", Journal of Finance, 1976, 31, pp. 1085-1100.

Mehra, Rajnish and Edward C. Prescott, "The Equity Premium: A Puzzle", Journal of Monetary Economics, 1985, 15, pp. 145-161.

National Income and Product Accounts, Fourth Quarter 1952 to 1999. Washington, DC: Board of Governors of the Federal Reserve System, 1952 to 1999.

National Survey of Small Business Finances, 1993 Survey. Washington, DC: Board of Governors of the Federal Reserve System, 1993.

Office of Federal Housing Enterprise Oversight, House Price Index 1993 to 1998. Department of Housing and Urban Development, Washington, DC, 1993 to 1998.

Parker, Robert P., "Improved Adjustments for Misreporting of Tax Return Information used to Estimate the National Income and Product Accounts, 1977", Survey of Current Business, 1984, 64(6), pp. 17-25.

Popkin, Joel, and Bruce A. Kirchhoff, "Business Survival Rates by Age Cohort of Business", U. S. Small Business Administration, 1991. 
Russo, J. Edward, and Paul J. H. Schoemaker, "Managing Overconfidence", Sloan Management Review, 1992, 33(2), pp. 7-17.

Survey of Consumer Finances, 1989, 1992, 1995, 1998. Washington, DC: Board of Governors of the Federal Reserve System, 1989, 1992, 1995, 1998.

U.S. Bureau of the Census, Department of Commerce. New Home Sales 1993 to 1995. Washington, DC.

U.S. Small Business Administration, Small Business Indicators, 1998. Washington, DC, 2000. Vissing-Jørgensen, Annette, "Comment on Heaton, J. and D. Lucas, Stock Prices and Fundamentals", NBER Macroeconomics Annual, 1999, pp. 242-253. 
Table 1: Summary Statistics on Entrepreneurs from the Survey of Consumer Finances

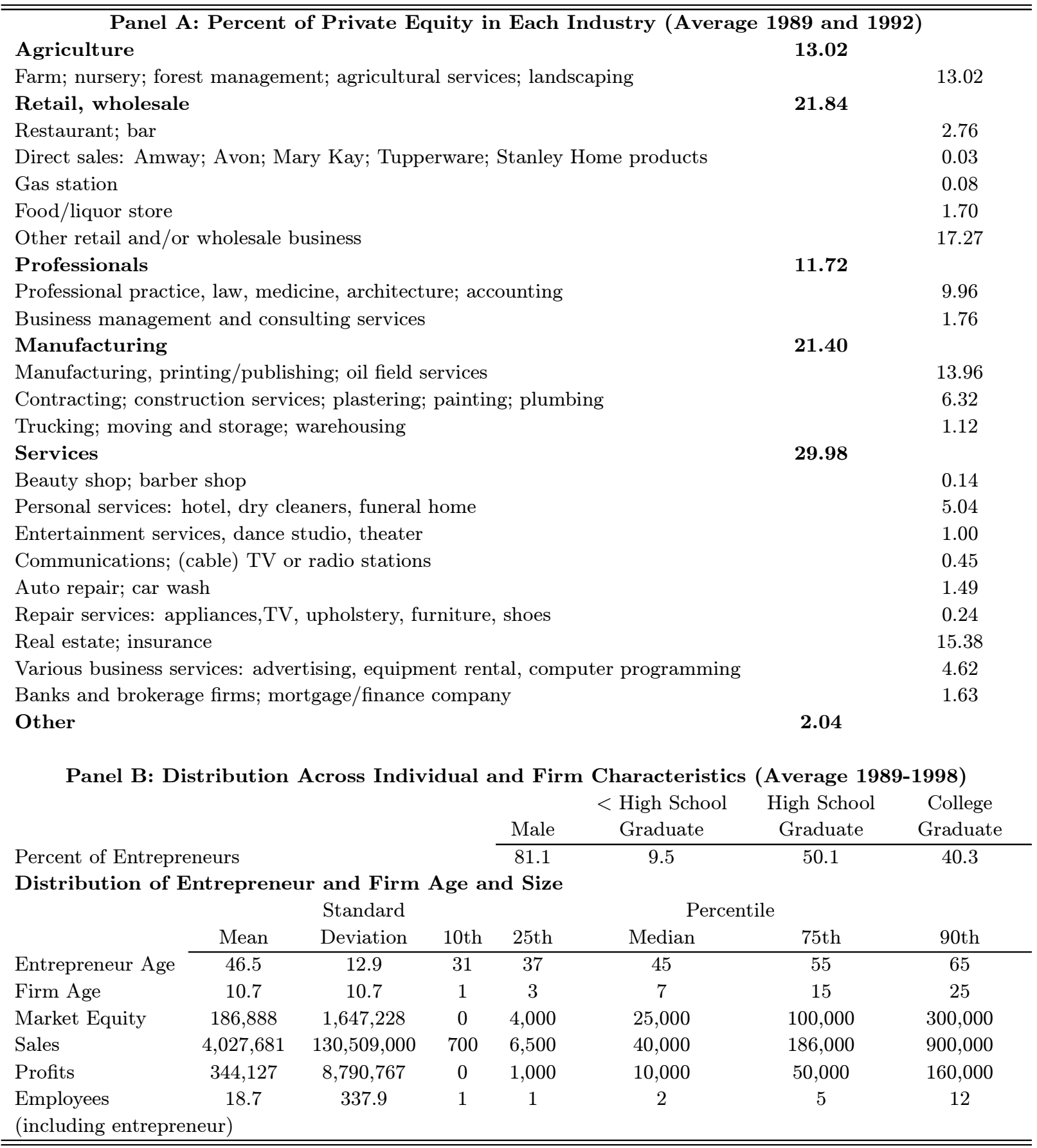

Notes: Summary statistics for households who own private equity are reported from the 1989, 1992, 1995, and 1998 SCF. Panel A contains summary statistics on the percent of equity each industry category accounted for in the 1989 and 1992 surveys. Industry statistics pertain to the largest three actively held private equity positions of each household. Private equity value is net equity if business were sold today, plus loans from household to business, minus loans from business to household. Panel B reports the distribution of entrepreneurs across demographic categories as well as the distribution of firm age and size. Panel B uses information for the firm in which the household has the largest actively managed position. The calculations include all firms with non-zero profits or non-zero market equity. For the entrepreneur level data, the entrepreneur is defined as the respondent (the male in couples) if he/she is self-employed and the self-employed spouse otherwise. All statistics reported are averages of all five SCF imputations. 
Table 2: Private Equity and Own Company Stock Ownership

\begin{tabular}{|c|c|c|c|c|c|}
\hline \multicolumn{6}{|c|}{ Panel A: Private Equity Ownership } \\
\hline & 1989 & $1992^{b}$ & 1995 & 1998 & Average \\
\hline \multicolumn{6}{|c|}{ Percent of Total Private Equity ${ }^{a}$ Owned By Households with } \\
\hline$\geq 25$ Percent net worth in private equity & 92.2 & 92.4 & 93.2 & 91.7 & 92.4 \\
\hline$\geq 50$ Percent net worth in private equity & 76.2 & 73.3 & 77.2 & 74.7 & 75.4 \\
\hline$\geq 75$ Percent net worth in private equity & 40.8 & 46.9 & 50.3 & 47.9 & 46.5 \\
\hline \multicolumn{6}{|c|}{$\begin{array}{l}\text { Mean Percent of Net Worth Invested in Private Equity } \\
\text { for Households with Positive Private Equity and Net Worth }\end{array}$} \\
\hline SCF weights only & 42.3 & 45.0 & 37.2 & 39.9 & 41.1 \\
\hline Weighted by net worth & 45.4 & 45.6 & 45.7 & 44.0 & 45.2 \\
\hline \multicolumn{6}{|c|}{$\begin{array}{l}\text { Mean Percent of Private Equity Held in One Actively Managed Firm } \\
\text { for Households with Positive Private Equity }\end{array}$} \\
\hline SCF weights only & 77.9 & 82.9 & 82.5 & 84.8 & 82.0 \\
\hline Weighted by amount of private equity & 72.8 & 70.7 & 74.0 & 73.5 & 72.8 \\
\hline
\end{tabular}

\section{Panel B: Own Company Stock Ownership in Public Firms}

\begin{tabular}{lcccccc} 
& 1989 & 1992 & 1995 & 1998 & Average \\
\cline { 2 - 6 } Percent of Total Public Equity Owned By Households & with & & & \\
$\geq 25$ Percent of their Public equity in own company & 13.4 & 12.5 & 10.9 & 12.5 & 12.3 \\
$\geq 50$ Percent of their Public equity in own company & 10.4 & 9.0 & 6.7 & 6.2 & 8.1 \\
$\geq 75$ Percent of their Public equity in own company & 5.6 & 4.3 & 3.7 & 3.6 & 4.3
\end{tabular}

Mean Percent of Net Worth Invested in Own Company Stock for Households with Positive Own Company Stock and Net Worth

$\begin{array}{llllll}\text { SCF weights only } & 8.7 & 6.9 & 10.8 & 10.4 & 9.2\end{array}$

Weighted by net worth

$\begin{array}{lllll}7.7 & 8.9 & 10.2 & 12.7 & 9.9\end{array}$

Mean Percent of Directly Held Public Equity in Own Company Stock for Households with Positive Own Company Stock ${ }^{c}$

$\begin{array}{llllll}\text { SCF weights only } & 77.7 & 77.5 & 69.1 & 71.0 & 73.8\end{array}$

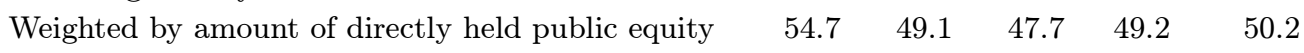

Mean Percent of Directly and Indirectly Held Public Equity in Own Company Stock for Households with Positive Own Company Stock ${ }^{d}$

\begin{tabular}{lrrrrr} 
SCF weights only & 67.0 & 55.6 & 46.9 & 40.2 & 52.4 \\
Weighted by total public equity held & 43.6 & 31.8 & 30.8 & 30.3 & 34.1 \\
\hline \hline
\end{tabular}

Notes: Private and own company stock ownership for households are reported from the 1989, 1992, 1995, and $1998 \mathrm{SCF}$, as well as the average across all four survey years. Panel A contains information on private equity ownership and Panel B contains information on own company stock holdings in public corporations, defined as ownership in a public firm for which a household member is or has been employed. All statistics reported are averages across all five SCF imputations.

${ }^{a}$ Ownership by households with negative net worth included in total private equity numbers.

${ }^{b}$ For 1992, data for two households with very small values of net worth for one of the imputations were deleted to get sensible results.

${ }^{c}$ In each year a few households report holding more directly held own company stock than their total direct stock holdings. For these, we set the percent of own company stock in directly held equity to one.

${ }^{d}$ In each year a few households report holding more directly held own company stock than their total direct and indirect stock holdings. For these, we set the percent of own company stock in directly and indirectly held equity to one. 
Table 3: The Size of Private and Public Equity Markets

\begin{tabular}{|c|c|c|c|c|}
\hline & 1989 & 1992 & 1995 & 1998 \\
\hline \multicolumn{5}{|l|}{ Panel A: Private Equity (\$ billion), SCF } \\
\hline Proprietors and Partnerships (Market Value) & 2,026 & 1,977 & 1,991 & 2,511 \\
\hline $\mathrm{S}$ and C Corporations ${ }^{a}$ (Market Value) & 1,661 & 1,780 & 2,302 & 3,226 \\
\hline Total Private Equity (Market Value) & 3,687 & 3,757 & 4,293 & 5,737 \\
\hline Public Equity (Market Value) & 1,587 & 2,102 & 3,439 & 7,256 \\
\hline Ratio: Private/Public Equity & 2.32 & 1.79 & 1.25 & 0.79 \\
\hline \multicolumn{5}{|l|}{ Profits ( $\$$ billion) } \\
\hline Pre-Tax, Proprietors and Partnerships & 335 & 430 & 458 & 534 \\
\hline After-Tax, S\&C Corporations ${ }^{b}$ & 267 & 288 & 341 & 496 \\
\hline Profits - Retained Earnings, P\&P (20 percent retained) & 268 & 344 & 367 & 427 \\
\hline Profits - Retained Earnings, S\&C (20/40 percent retained) & 175 & 194 & 244 & 355 \\
\hline \multicolumn{5}{|l|}{ Labor Income ( $\$$ billion) } \\
\hline Total salary paid to self-employed managers & 141 & 191 & 159 & 300 \\
\hline \multicolumn{5}{|l|}{$($ Hours worked $) \times(\text { estimated wage rate })^{c}$} \\
\hline for entrepreneurs with no self-employment salary & 175 & 193 & 229 & 232 \\
\hline Proprietors and Partnerships & 152 & 155 & 200 & 172 \\
\hline $\mathrm{S}$ and $\mathrm{C}$ Corporations & 23 & 38 & 30 & 60 \\
\hline Price-to-Earnings Ratio & 5.4 & 4.7 & 5.0 & 5.1 \\
\hline Price-to-Dividends Ratio ${ }^{d}$ & 13.8 & 10.9 & 11.2 & 10.4 \\
\hline \multicolumn{5}{|l|}{ Panel B: Private Equity ( $\$$ billion), FFA/NIPA } \\
\hline Equity in Noncorporate Business ${ }^{e}$ & 3,102 & 3,127 & 3,599 & 4,394 \\
\hline -Value of $1-4$ Family Rental Properties & 942 & 1,003 & 1,135 & 1,272 \\
\hline$=$ Proprietors and Partnerships (Market Value) & 2,160 & 2,124 & 2,463 & 3,122 \\
\hline $\mathrm{S}$ and $\mathrm{C}$ Corporations (Market Value) (estate multiplier $=2$ ) & 1,412 & 1,220 & 1,585 & 2,067 \\
\hline $\mathrm{S}$ and $\mathrm{C}$ Corporations (Market Value) (estate multiplier $=3$ ) & 2,117 & 1,830 & 2,377 & 3,101 \\
\hline Total Private Equity (Market Value) (estate multiplier = 2) & 3,571 & 3,344 & 4,048 & 5,190 \\
\hline Total Private Equity (Market Value) (estate multiplier = 3) & 4,277 & 3,954 & 4,841 & 6,223 \\
\hline Ratio: Private/Public Equity (estate multiplier $=2$ ) & 1.08 & 0.76 & 0.60 & 0.39 \\
\hline Ratio: Private $/(0.70 \times$ Public $)$ Equity & 1.55 & 1.09 & 0.86 & 0.56 \\
\hline \multicolumn{5}{|l|}{ Income and Dividends ( $\$$ billion $)$} \\
\hline Proprietors' Income & 362 & 434 & 498 & 624 \\
\hline Adjusted Proprietor's Income - Retained Earnings ${ }^{f}$ & 209 & 247 & 336 & 519 \\
\hline Dividends, S and C Corporations ${ }^{g}$ & 147 & 176 & 236 & 376 \\
\hline \multicolumn{5}{|c|}{ Panel C: Public Equity (\$ billion), Center for Research in Security Prices } \\
\hline Market Value & 3,292 & 4,376 & 6,734 & 13,217 \\
\hline New Issues and Takeovers, 3-Year Total ( $\$$ billion) & & 1990-92 & 1993-95 & $1996-98$ \\
\hline New Issues & & 42 & 76 & 110 \\
\hline SDC M\&A Adjustment to Private Equity ${ }^{h}$ & & 55 & 129 & 421 \\
\hline SDC Private Acquisitions of Public Firms & & 34 & 31 & 58 \\
\hline
\end{tabular}


Notes: The aggregate market values of all private and public equity as well as various profit measures are reported below. Estimates are obtained from two sources. Panel A contains data from the 1989, 1992, 1995, and 1998 SCF, averaging over all 5 imputations. Panel B contains data from the FFA/NIPA over the same years. Panel C contains data on publicly traded equity (NYSE, AMEX, and NASDAQ) from the Center for Research in Security Prices (CRSP) over the same period.

${ }^{a}$ Included in this category are firms of unknown type and other types of corporations.

${ }^{b}$ After tax profits assume a 30 percent corporate tax rate which only applies to $\mathrm{C}$ and other corporations and type unknown firms. Profits from S corporations are included pre-tax.

${ }^{c}$ Hours worked by head and/or spouse for self-employed persons with positive equity in a business in which they have an active management role and who did not report receiving a salary. Estimated wage rates are determined by first regressing hourly wage rates of household members who are not self-employed on educational and demographic attributes, and then using the regression equation to predict wage rates of self-employed household members with no salary reported.

$d$ 'Dividends' refer to profits minus retained earnings minus the labor adjustment for self-employed individuals who do not report a salary.

${ }^{e}$ Equity in noncorporate business is defined as (tangible assets + financial assets) - liabilities. Tangible assets consist of real estate (at estimated market value) and equipment, software, and inventories (at estimated replacement cost).

$f$ We adjust $\mathrm{P} \& \mathrm{P}$ income in three ways. First, we change the adjustment for misreporting of profits on income tax returns to be 75 percent in each year from 1959 onward, implying that for every $\$ 1$ of profits reported to the IRS, adjusted profits are $\$ 1.75$. This differs from the income underreporting adjustment made in the FFA, which fluctuates dramatically over time (from a low of 33 percent in 1959 to a high of 200 percent in 1982, see NIPA Table 8.23). Second, we subtract the capital consumption adjustment included in NIPA profits from earnings to get a measure of the actual profit flows to proprietors. To the extent that tax laws allow for different depreciation than the true economic depreciation, the difference will show up in the capital gain component of returns. Third, as a measure of actual retained earnings in the firm, we add capital expenditures plus net acquisition of financial assets minus net increase in liabilities (excluding "proprietor net investment"). This measures the amount owners must have invested to cover firm investment, whether from profits or additional paid in funds.

${ }^{g}$ We estimate dividends paid out by private S\&C corporations as total dividends paid by all corporations (from NIPA) minus dividends paid by public corporations (from CRSP). In addition, we add 20 percent of the NIPA income underreporting adjustment made to total corporate profits.

$h$ The total change to private equity totals from merger and acquisition activity obtained from SDC and Table 6 . Table 6 describes the various adjustments to the private equity totals. 
Table 4: The Returns to Private Equity (1990 to 1998)

\begin{tabular}{|c|c|c|c|c|c|c|c|c|c|c|}
\hline \multicolumn{8}{|c|}{ Adjustments for } & \multicolumn{3}{|c|}{ Annual Returns } \\
\hline \multicolumn{2}{|c|}{ Retained Earnings } & \multicolumn{3}{|c|}{ Firm } & \multirow[b]{2}{*}{$M \& A^{b}$} & \multirow{2}{*}{$\begin{array}{c}\text { Tax } \\
\text { Evasion }\end{array}$} & \multirow{2}{*}{$\begin{array}{l}\text { P\&P- } \\
\text { S\&C }\end{array}$} & \multicolumn{3}{|c|}{ (percent per year) } \\
\hline C Corporations & $\mathrm{P}, \mathrm{P}, \& \mathrm{~S}$ & Labor $^{a}$ & Births & IPOs & & & & $1990-92$ & $1993-95$ & $1996-98$ \\
\hline \multicolumn{11}{|c|}{ Panel A: Private Equity Returns } \\
\hline \multicolumn{11}{|c|}{ Data from the SCF } \\
\hline 1. All $\quad 0.40$ & 0.20 & - & - & - & - & Yes & & 12.3 & 17.0 & 22.2 \\
\hline 2. $\mathrm{P} \& \mathrm{P}$ & 0.20 & - & - & - & - & Yes & - & 12.6 & 15.6 & 23.0 \\
\hline 3. $\mathrm{S} \& \mathrm{C}$ & & - & - & - & - & Yes & - & 12.0 & 18.5 & 21.4 \\
\hline 4. All & 0.20 & Yes & - & - & - & Yes & & 8.2 & 12.7 & 18.4 \\
\hline 5. $\mathrm{P} \& \mathrm{P}$ & 0.20 & Yes & - & - & - & Yes & - & 6.4 & 9.4 & 15.9 \\
\hline 6. $\mathrm{S} \& \mathrm{C}$ & & Yes & - & - & - & Yes & - & 10.9 & 16.9 & 20.6 \\
\hline 7. All & 0.20 & Yes & Yes & - & - & Yes & & 7.5 & 11.6 & 16.4 \\
\hline 8. All & 0.20 & Yes & Yes & Yes & - & Yes & & 7.8 & 12.1 & 17.0 \\
\hline 9. All & 0.20 & Yes & Yes & Yes & Yes & Yes & & 8.2 & 13.0 & 19.4 \\
\hline 10. $\mathrm{P} \& \mathrm{P}$ & 0.20 & Yes & Yes & Yes & Yes & Yes & Yes & 7.4 & 8.9 & 15.4 \\
\hline 11. $\mathrm{S} \& \mathrm{C}$ & & Yes & Yes & Yes & Yes & Yes & Yes & 9.7 & 17.6 & 22.8 \\
\hline \multirow[t]{2}{*}{ 12. All } & 0 & Yes & Yes & Yes & Yes & Yes & & 10.3 & 15.4 & 21.7 \\
\hline & $\mathrm{P} \& \mathrm{P}$ & & & & & & & & & \\
\hline \multicolumn{11}{|c|}{ Data from the FFA/NIPA } \\
\hline $\begin{array}{l}\text { 13. All actual } \\
\text { (estate multiplier }\end{array}$ & actual & Yes & - & - & - & Yes & & 4.1 & 16.7 & 22.4 \\
\hline $\begin{array}{l}\text { 14. All actual } \\
\text { (estate multiplier }\end{array}$ & actual & Yes & - & - & - & Yes & & 2.1 & 14.7 & 19.4 \\
\hline 15. $\mathrm{P} \& \mathrm{P}$ & actual & Yes & - & - & - & Yes & - & 1.9 & 12.3 & 19.8 \\
\hline $\begin{array}{l}\text { 16. } \mathrm{S} \& \mathrm{C} \text { actual } \\
\text { (estate multiplier }\end{array}$ & & Yes & - & - & - & Yes & - & 6.5 & 22.6 & 25.5 \\
\hline $\begin{array}{l}\text { 17. } \mathrm{S} \& \mathrm{C} \text { actual } \\
\text { (estate multiplier }\end{array}$ & & Yes & - & - & - & Yes & - & 2.4 & 17.7 & 19.7 \\
\hline \multicolumn{11}{|c|}{ Panel B: Public Equity Returns } \\
\hline 18. CRSP Data, V & le-Weighte & Index & & & & & & 11.0 & 14.6 & 24.7 \\
\hline 19. CRSP Data, S & llest Decil & & & & & & & 30.5 & 20.3 & 22.0 \\
\hline 20. SCF Data & & & & & & & & 13.2 & 20.7 & 30.0 \\
\hline 21. SCF Data, wit & [PO and $\mathrm{T}$ & keover $\mathrm{A}$ & djustmer & & & & & 13.1 & 20.3 & 29.8 \\
\hline
\end{tabular}

Notes: Panel A reports the returns to all private equity based on estimates of the size of privately held equity and their earnings from Table 3. The return estimates pertain to data from the 1989, 1992, 1995, and 1998 SCF as well as the FFA/NIPA. Returns are calculated using various assumptions about retained earnings, the labor component of profits, sample composition changes due to entry and exit of firms, and underreported profits due to tax evasion. When separating returns by Proprietorships and Partnerships (P\&P) versus $\mathrm{S}$ and $\mathrm{C}$ corporations (S\&C), we assume 2.1 percent of P\&Ps transfer to corporations in order to account for the inflow and outflow of equity values to both types of firms (denoted by a 'yes' in the P\&P-S\&C column). Panel $\mathrm{B}$ reports returns to publicly traded equity over the same time period from CRSP. All returns are nominal geometric average returns over the three subperiods from 1990 to 1998.

${ }^{a}$ When salaries are not reported for self-employed households, the salary adjustment is the hours worked by head or spouse for self-employed persons times the estimated hourly wage rate for the person. Estimated wage rates are determined by first regressing hourly wage rates of household members who are not self-employed on educational and demographic attributes, and then using the regression equation to predict wage rates of self-employed household members who do not report a salary.

${ }^{b}$ Obtained from Securities Data Corporation for each year over the survey period. A summary of the adjustments are described and reported in Table 6 .

${ }^{c}$ IPO and takeover adjustments assume households own 70 percent of all public equity. This corresponds approximately to the share of corporate equity owned by households (directly and indirectly) over this period in the FFA. 
Table 5: The Returns to Private Equity (1952 to 1999)

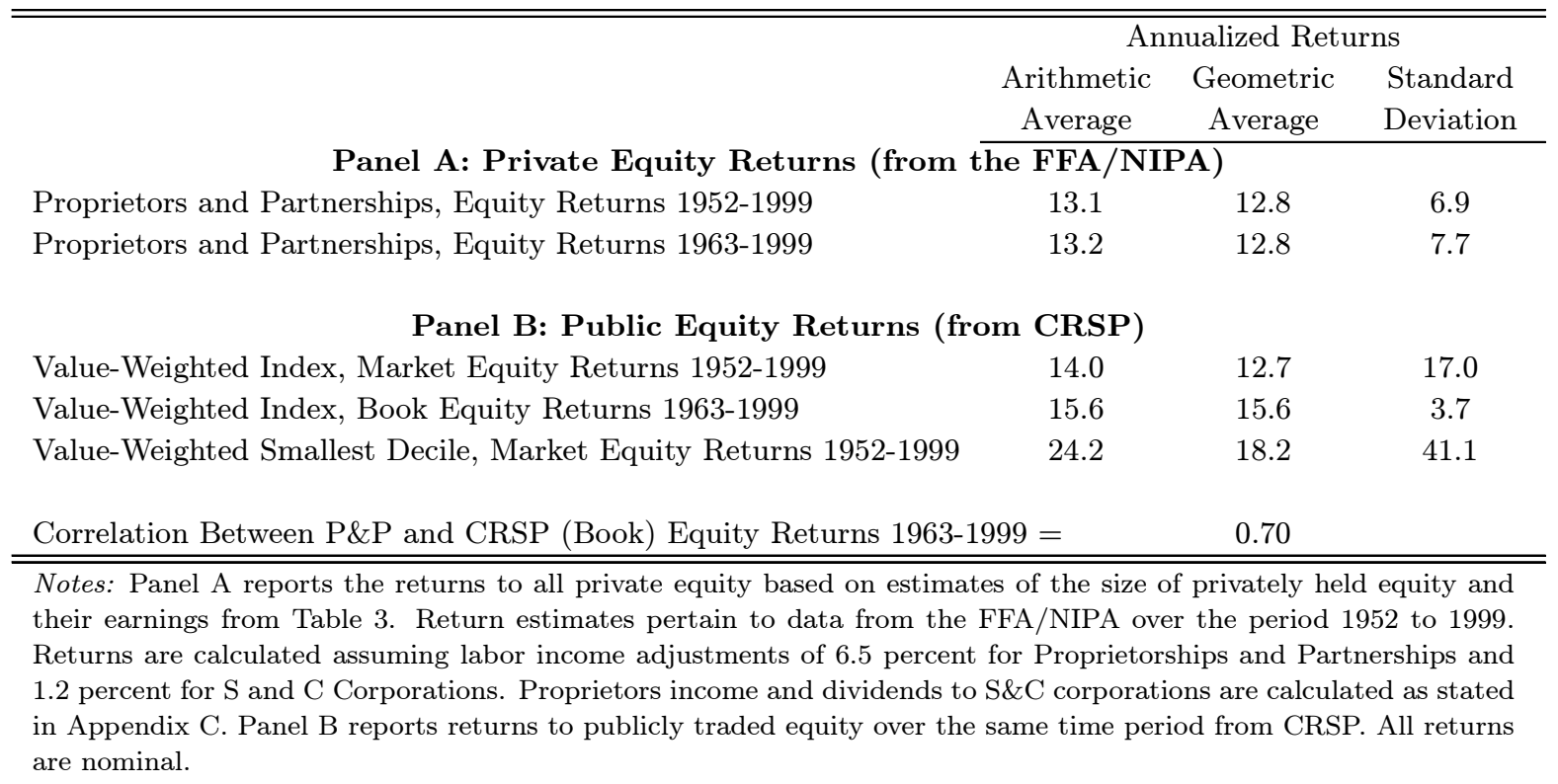


Table 6: Merger and Acquisition Activity in Private and Public Firms

\begin{tabular}{|c|c|c|c|c|c|c|c|c|c|}
\hline \multirow{3}{*}{$\begin{array}{l}\text { Acquirer: } \\
\text { Target: }\end{array}$} & \multicolumn{3}{|c|}{$1990-1992$} & \multicolumn{3}{|c|}{ ב1993-1995 } & \multicolumn{3}{|c|}{ "1996-1998 } \\
\hline & Public & Private & Private & Public & Private & Private & Public & Private & Private \\
\hline & Private & Private & Public & Private & Private & Public & Private & Private & Public \\
\hline \multicolumn{10}{|c|}{ All Acquirers, All Targets } \\
\hline Value (\$ mill.) & $\$ 62,236$ & $\$ 24,059$ & $\$ 70,989$ & $\$ 109,702$ & $\$ 32,358$ & $\$ 90,217$ & $\$ 287,669$ & $\$ 69,727$ & $\$ 136,736$ \\
\hline \#Deals & 6,290 & 4,338 & 2,397 & 10,451 & 5,716 & 3,828 & 18,942 & 8,118 & 3,723 \\
\hline \#Deals w/price & 2,718 & 857 & 1,657 & 5,088 & 1,312 & 2,522 & 8,943 & 1,993 & 2,477 \\
\hline Scaled Value & $\$ 133,847$ & $\$ 43,741$ & $\$ 85,275$ & $\$ 211,678$ & $\$ 85,410$ & $\$ 106,895$ & $\$ 610,613$ & $\$ 196,099$ & $\$ 158,987$ \\
\hline \multicolumn{10}{|c|}{ All Acquirers, Domestic Targets } \\
\hline Value (\$ mill.) & $\$ 30,579$ & $\$ 11,116$ & $\$ 30,310$ & $\$ 67,448$ & $\$ 14,193$ & $\$ 26,764$ & $\$ 192,238$ & $\$ 27,519$ & $\$ 50,155$ \\
\hline \#Deals & 3,141 & 1,181 & 1,221 & 5,737 & 1,535 & 1,814 & 10,711 & 2,467 & 1,787 \\
\hline \#Deals w/price & 1,367 & 268 & 1,021 & 2,960 & 378 & 1,516 & 5,126 & 558 & 1,367 \\
\hline Scaled Value & $\$ 63,720$ & $\$ 20,799$ & $\$ 33,824$ & $\$ 131,533$ & $\$ 36,593$ & $\$ 31,261$ & $\$ 407,889$ & $\$ 77,468$ & $\$ 58,073$ \\
\hline \multicolumn{10}{|c|}{ All Acquirers, Domestic Targets, Debt or Internally Funded } \\
\hline Value (\$ mill.) & $\$ 3,483$ & $\$ 3,068$ & $\$ 8,794$ & $\$ 12,015$ & $\$ 3,568$ & $\$ 4,632$ & $\$ 28,592$ & $\$ 5,832$ & $\$ 16,806$ \\
\hline \#Deals & 163 & 88 & 70 & 391 & 102 & 57 & 511 & 84 & 86 \\
\hline \#Deals w/price & 136 & 30 & 61 & 352 & 59 & 48 & 424 & 46 & 77 \\
\hline Scaled Value & $\$ 7,342$ & $\$ 5,238$ & $\$ 9,250$ & $\$ 23,413$ & $\$ 9,756$ & $\$ 5,533$ & $\$ 60,403$ & $\$ 13,371$ & $\$ 19,198$ \\
\hline \multicolumn{10}{|c|}{ Foreign Acquirers, Domestic Targets } \\
\hline Value (\$ mill.) & $\$ 6,400$ & $\$ 5,919$ & $\$ 12,574$ & $\$ 7,654$ & $\$ 6,110$ & $\$ 10,831$ & $\$ 17,836$ & $\$ 11,738$ & $\$ 19,858$ \\
\hline \#Deals & 432 & 239 & 588 & 425 & 304 & 1,013 & 737 & 447 & 970 \\
\hline \#Deals w/price & 265 & 87 & 520 & 268 & 133 & 892 & 454 & 161 & 760 \\
\hline Scaled Value & $\$ 13,242$ & $\$ 10,439$ & $\$ 14,002$ & $\$ 15,186$ & $\$ 14,902$ & $\$ 12,937$ & $\$ 37,734$ & $\$ 32,293$ & $\$ 23,073$ \\
\hline \multicolumn{10}{|c|}{ Domestic Acquirers, Foreign Targets, Equity Funded } \\
\hline Value (\$ mill.) & $\$ 2,081$ & $\$ 222$ & $\$ 8,635$ & $\$ 6,138$ & $\$ 631$ & $\$ 9,306$ & $\$ 16,907$ & $\$ 1,893$ & $\$ 4,595$ \\
\hline \#Deals & 374 & 100 & 84 & 728 & 195 & 151 & 1,548 & 299 & 110 \\
\hline \#Deals w/price & 114 & 15 & 52 & 220 & 28 & 77 & 518 & 50 & 66 \\
\hline Scaled Value & $\$ 3,869$ & $\$ 295$ & $\$ 10,909$ & $\$ 11,690$ & $\$ 1,317$ & $\$ 11,628$ & $\$ 36,187$ & $\$ 3,626$ & $\$ 5,083$ \\
\hline \multicolumn{10}{|c|}{ Domestic Acquirers, All Targets, Equity Funded } \\
\hline Value (\$ mill.) & $\$ 23,291$ & $\$ 4,216$ & $\$ 20,262$ & $\$ 55,227$ & $\$ 6,201$ & $\$ 21,784$ & $\$ 165,406$ & $\$ 15,420$ & $\$ 25,138$ \\
\hline \#Deals & 2,938 & 988 & 666 & 5,683 & 1,359 & 911 & 11,054 & 2,258 & 872 \\
\hline \#Deals w/price & 1,094 & 175 & 510 & 2,590 & 235 & 667 & 4,801 & 414 & 623 \\
\hline Scaled Value & $\$ 47,951$ & $\$ 8,483$ & $\$ 24,306$ & $\$ 106,954$ & $\$ 16,085$ & $\$ 25,938$ & $\$ 351,533$ & $\$ 41,536$ & $\$ 28,861$ \\
\hline \multirow[t]{2}{*}{$\Delta$ Total Value ${ }^{a}$} & $\$ 63,720$ & $\$ 15,381$ & $\$ 24,306$ & $\$ 131,533$ & $\$ 23,341$ & $\$ 25,938$ & $\$ 407,889$ & $\$ 42,038$ & $\$ 28,861$ \\
\hline & (1) & $(2)$ & (3) & (1) & $(2)$ & $(3)$ & (1) & $(2)$ & (3) \\
\hline \multicolumn{10}{|c|}{ Total $\Delta$ Private Equity Value } \\
\hline$(1)+(2)-(3)=$ & & $\$ 54,795$ & & & $\$ 128,936$ & & & $\$ 421,066$ & \\
\hline
\end{tabular}

Notes: The total dollar amount (in $\$$ millions) and total number of transactions of merger and acquisition activity in private and public firms are reported below over the three subperiods 1990 to 1992, 1993 to 1995, and 1996 to 1998 . Data are from Securities Data Corporation (SDC) and correspond only to completed transactions. Statistics are reported separately for public firm acquisitions of private firms, private firm acquisitions of other private firms, and private firm acquisitions of public firms, each broken down further into domestic acquirers and targets, foreign acquirers and targets, and acquisitions funded with debt or internal cash and equity. Also reported are the number of transactions with available price information and a scaled dollar value for all deals using an estimated value for deals with missing transaction value, as detailed in Appendix B. The total change in private equity totals from this activity are reported at the bottom of the table.

${ }^{a}$ Calculated as follows: For column (1) (Private-to-Public) = scaled value of all acquisitions of domestic targets. For column (2) $($ Private-to-Private $)=$ scaled value of all acquisitions of domestic targets funded by debt or internal funds + scaled value of foreign acquisitions of domestic targets - scaled value of domestic acquisitions of foreign targets funded by equity. For column (3) (Public-to-Private) = scaled value of domestic acquisitions of all targets funded by equity. 
Figure 1: The Returns to Private and Public Equity (1963 to 1999)

Notes: The annual returns to the index of FFA/NIPA private proprietor and partnership equity and book equity returns to the index of public corporations from the CRSP-Compustat universe are plotted below over the period 1963 to 1999.

- FFA/NIPA $\mathrm{P} \& \mathrm{P}$ return

$\triangle$ Public equity book return

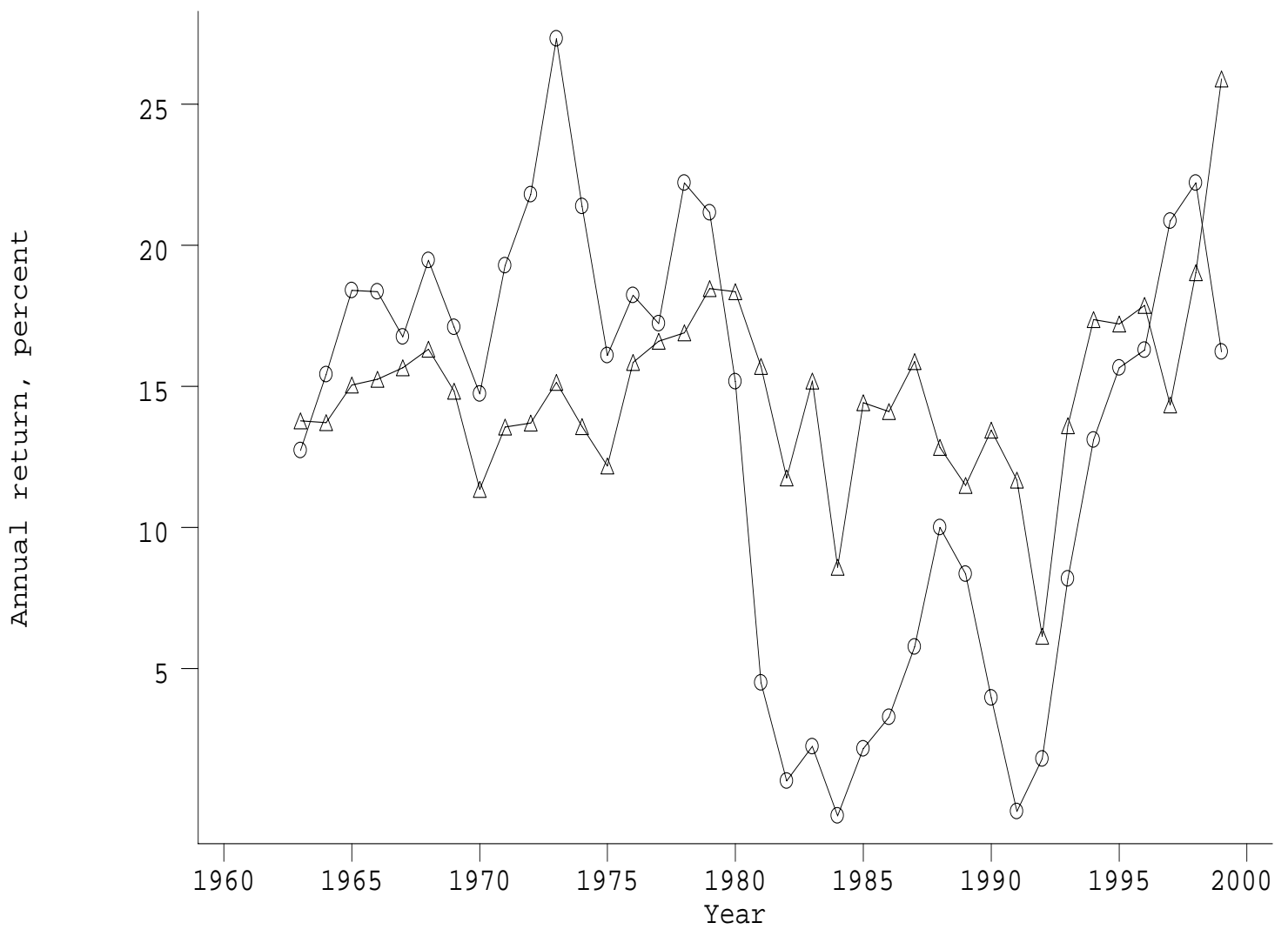


Figure 2: The Conditional Distribution of Returns to Private Equity Across Households

Notes: Household data from the $1989 \mathrm{SCF}$ are used to plot the returns to private equity investment in surviving firms. The top left plot shows the histogram of geometric average annual capital gains accrued across households, defined as $\left(\frac{\text { Value at the time of the survey }}{\text { Value of original investment }}\right)^{1 /(\text { Years since founded/acquired })}$

- 1. The top right plot shows the histogram of earnings rates (earnings in the year prior to the survey divided by market value of equity) accrued across households. The bottom left plot shows the histogram across households of the geometric average return on investment if households had instead invested their wealth in the CRSP value weighted index of all publicly traded equity over the same horizon as their private equity investment. The bottom right plot shows the histogram across households of the total average return (capital gain plus earnings, where 30 percent of earnings are assumed to be retained in the firm) on private equity in excess of the CRSP index return over each household's holding period.
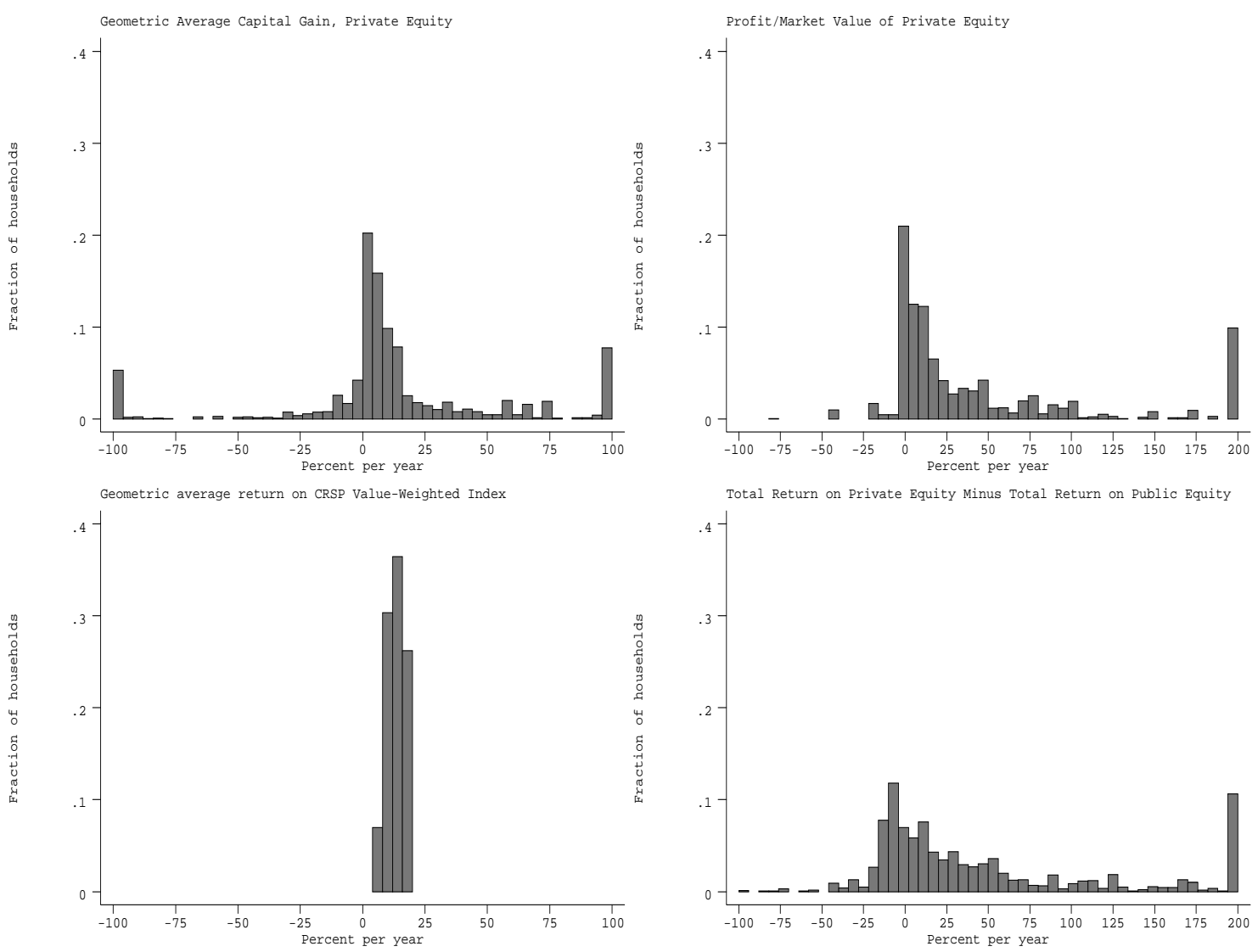